\title{
The Role of Human $\gamma \delta$ T Cells in Anti-Tumor Immunity and Their Potential for Cancer Immunotherapy
}

\author{
Yuxia Liu and Cai Zhang * \\ Institute of Immunopharmaceutical Sciences, School of Pharmaceutical Sciences, Cheeloo College of Medicine, \\ Shandong University, 44 Wenhua West Road, Jinan 250012, China; 201816090@mail.sdu.edu.cn \\ * Correspondence: caizhangsd@sdu.edu.cn; Tel.: +86-531-8838-3782
}

Received: 22 March 2020; Accepted: 9 May 2020; Published: 13 May 2020

check for updates

\begin{abstract}
T cells are a distinct subset of T cells whose T cell receptors consist of $\gamma$ chains and $\delta$ chains, different from conventional $\alpha \beta$ T cells. $\gamma \delta$ T cells are considered as a member of the innate immunity because of their non-MHC restricted antigen recognition, rapid response to invading pathogens and sense early changes of malignant cells. Upon activation, they can further promote the activation of adaptive immune cells, such as T cells and B cells, by secreting various cytokines. Thus, $\gamma \delta \mathrm{T}$ cells are regarded as a bridge between innate immunity and acquired immunity. $\gamma \delta \mathrm{T}$ cells are involved in a variety of immune response processes, including immune defense and immune surveillance against infection and tumorigenesis. $\gamma \delta \mathrm{T}$ cells recognize multiple tumor-associated antigens or molecules in T cell receptors (TCRs)-dependent and natural killer cell receptors (NKRs)-dependent ways. $\gamma \delta \mathrm{T}$ cells not only display a direct killing capacity on a variety of tumors, but also exert anti-tumor immune responses indirectly by facilitating the function of other immune cells, such as dendritic cells (DCs), B cells and $\mathrm{CD}^{+} \mathrm{T}$ cells. In this review, we summarize the major subpopulations, the tumor recognition mechanisms, and the anti-tumor effects of human $\gamma \delta \mathrm{T}$ cells, particularly the potential of $\gamma \delta$ T cells for cancer immunotherapy.
\end{abstract}

Keywords: $\gamma \delta \mathrm{T}$ cells; anti-tumor effect; cancer immunotherapy

\section{Introduction}

Human $\gamma \delta$ T cells are unique innate immune cells, accounting for $1-5 \%$ of lymphocytes in peripheral blood. They mainly distribute in the gut mucosa, skin and other mucosal tissues and participate in a variety of immune response and immune regulation processes, such as mediating immune inflammatory response, directly recognizing and killing tumors [1,2]. $\gamma \delta \mathrm{T}$ cells have gained more attention because they can quickly generate immune responses to a variety of invading pathogens and early changes of malignancy, which is likely to relate to non-MHC restricted antigen recognition, thereby, $\gamma \delta \mathrm{T}$ cells, together with macrophages and neutrophils, contribute to the first line of defense against foreign infections [2,3]. Upon activation, they can further promote the activation of adaptive immune cells, such as T cells and B cells, by secreting various cytokines. Thus, $\gamma \delta \mathrm{T}$ cells are regarded as a bridge between innate immunity and acquired immunity [4,5]. $\gamma \delta \mathrm{T}$ cells not only play a significant role in resisting external infections, but also play an important role in tumor immunity [2,6]. Previous studies have found that $\gamma \delta \mathrm{T}$ cells have powerful anti-tumor efficacy on a variety of tumors, such as breast cancer, colon cancer, lung cancer and others [7-9]. $\gamma \delta \mathrm{T}$ cells recognize tumors through $\mathrm{T}$ cell receptors (TCRs) and natural killer cell receptors (NKRs) [10]. On one hand, $\gamma \delta$ T cells can directly kill tumor cells through their strong cytotoxic effects, which usually depends on their production of interferon $\gamma(\mathrm{IFN} \gamma)$ and tumor necrosis factor- $\alpha$ (TNF- $\alpha)[6]$. On the other hand, they can also indirectly exert 
anti-tumor effects by facilitating the function of other immune cells, such as enhancing the ability of dendritic cells (DCs) to present antigens or enhancing the ability of cytotoxic $\mathrm{T}$ cells to kill tumor cells [11,12].

Due to the unique features of $\gamma \delta \mathrm{T}$ cells, such as the not MHC-restriction for tumor cell recognition and quickly production of abundant cytokines and potent cytotoxicity in response to malignancies, the anti-tumor effects of $\gamma \delta \mathrm{T}$ cells have demonstrated unique superiority, and $\gamma \delta \mathrm{T}$ cell-based cancer immunotherapy has great promise in tumor therapy $[12,13]$. In this review, we summarize the major characteristics of human $\gamma \delta \mathrm{T}$ cells, tumor cell recognition by $\gamma \delta \mathrm{T}$ cells, the anti-tumor mechanism of $\gamma \delta \mathrm{T}$ cells as well as their application and some new strategies of $\gamma \delta \mathrm{T}$ cells for cancer immunotherapy.

\section{Diversity of Human $\gamma \delta$ T Cell Subsets}

Human $\gamma \delta$ T cells can be divided into a variety of subsets based on their TCR usage, cellular phenotype and function [11,14]. (I) $\gamma \delta \mathrm{T}$ cell subsets classified according to the usage of TCR $\gamma$-chain or $\delta$-chain. Generally, human $\gamma \delta \mathrm{T}$ cells can be divided into four major groups, V $\delta 1, \mathrm{~V} \delta 2, \mathrm{~V} \delta 3$ and V $\delta 5$ $\gamma \delta$ T cells, based on the differences of TCR $\delta$-chain [15-17] (Table 1). They have different distribution and different function. Human V $\delta 1^{+} \gamma \delta \mathrm{T}$ cells are mainly distributed in the skin, small intestine and other mucosal tissues [18]. They are also found in small amounts in the liver and spleen [19]. V $\delta 1$ can co-express with various $\mathrm{V} \gamma$ chains $(\mathrm{V} \gamma 2, \mathrm{~V} \gamma 3, \mathrm{~V} \gamma 4, \mathrm{~V} \gamma 5, \mathrm{~V} \gamma 8$ and $\mathrm{V} \gamma 10)$ to form different $\gamma \delta \mathrm{T}$ cell subsets [20]. V $\delta 1^{+} \gamma \delta \mathrm{T}$ cells exhibit high anti-tumor activity against multiple cancers, such as chronic lymphoid leukemia, multiple myeloma, breast cancer, colorectal cancer and other cancers $[7,18,21,22]$. $\mathrm{V} \delta 2^{+} \gamma \delta \mathrm{T}$ cells mainly exist in peripheral blood and are the main $\gamma \delta \mathrm{T}$ cells involved in blood circulation. During TCR $\gamma \delta$ rearrangement, $\mathrm{V} \delta 2$ is almost exclusively co-expressed with $\mathrm{V} \gamma 9$ to form $\mathrm{V} \gamma 9 \mathrm{~V} \delta 2$ $\mathrm{T}$ cells, which can recognize phosphoantigen and have strong anti-tumor ability against tumors such as cholangiocarcinoma, primary glioblastoma, breast cancer and other cancers [23-25]. V $\gamma 9 \mathrm{~V} \delta 2 \mathrm{~T}$ cells can also inhibit tumor cell proliferation and promote tumor cell apoptosis [26]. In addition, a recent study reported that human $\mathrm{V} \delta 2^{+} \gamma \delta \mathrm{T}$ subpopulation includes a distinct $\mathrm{V} \gamma 9^{-}$subset with adaptive characteristics, exerting distinct functions in microbial immunosurveillance [27]. $V \delta 3^{+} \gamma \delta \mathrm{T}$ cells mainly exist in the liver and small intestine epithelium. There are few studies on its effect on tumor process [28]. $\mathrm{V} \delta 5^{+} \gamma \delta \mathrm{T}$ cells co-expressing $\mathrm{V} \gamma 4$ recognize endothelial protein $\mathrm{C}$ receptor (EPCR) on cytomegalovirus (CMV)-infected epithelial cells and epithelial tumor cells via TCR [29]. (II) $\gamma \delta$ T cell subsets classified according to $\gamma \delta \mathrm{T}$ cell phenotype. Human $\mathrm{V} \gamma 9 \mathrm{~V} \delta 2 \mathrm{~T}$ cells express some surface markers associated with functional phenotypes. They can be divided into four distinct subsets: naive, central memory, effector memory, and terminal differentiated cells, based on the cell surface expression of CD27 and CD45RA [30]. Naive $\left(\mathrm{CD} 27^{+} \mathrm{CD}^{2} 5 \mathrm{RA}^{+}\right)$and central memory $\left(\mathrm{CD} 27^{+} \mathrm{CD} 45 \mathrm{RA}^{-}\right) \mathrm{V} \gamma 9 \mathrm{~V} \delta 2$ $\mathrm{T}$ cells are inclined to stay in the lymph nodes and lack immediate effector functions, while effector memory $\left(\mathrm{CD} 27^{-} \mathrm{CD} 4 \mathrm{RA}^{-}\right)$and terminally differentiated $\left(\mathrm{CD} 27^{-} \mathrm{CD}^{-} 5 \mathrm{RA}^{+}\right) \mathrm{V} \gamma 9 \mathrm{~V} \delta 2 \mathrm{~T}$ cells tend to move toward inflammatory sites and exert immediate effector functions [30]. These distinct subsets display different function in response to bacterial and viral infection. (III) $\gamma \delta \mathrm{T}$ cell subsets classified according to cellular function. Similar to $\alpha \beta$ T cells, $\gamma \delta$ T cells can be divided into different subsets based on their different functions, such as $\gamma \delta \mathrm{T} 1, \gamma \delta \mathrm{T} 17$, follicle-assisted $\gamma \delta \mathrm{T}$ ( $\gamma \delta \mathrm{Tfh}$ ), regulatory $\gamma \delta \mathrm{T}$ ( $\gamma \delta$ Treg) and memory $\gamma \delta$ T cells [31]. $\gamma \delta$ T1 cells are mainly IFN- $\gamma$-producing cells. Human peripheral blood $\gamma \delta \mathrm{T}$ cells (mainly $\mathrm{V} \gamma 9 \mathrm{~V} \delta 2 \mathrm{~T}$ cells) can produce IFN $-\gamma$ in the stimulation of phosphoantigen (such as isopentenyl pyrophosphate, IPP) accompanied by IL-12 and anti-IL-4 antibodies [32]. $\gamma \delta$ T17 cells are mainly IL-17-producing $\gamma \delta \mathrm{T}$ cells. IL-17 is a pro-inflammatory factor associated with the development of chronic tissue inflammation and autoimmune diseases [33]. $\gamma \delta \mathrm{T} 17$ cells are rarely found in healthy individuals, but accumulate in tissues with tumor and inflammation, which suggests that $\gamma \delta \mathrm{T} 17$ cells are associated with tumor progression $[34,35] . \gamma \delta$ Tfh cells have similar functions to traditional Tfh cells, and can promote B cell maturation and facilitate the ability of B cells to produce antibodies [36]. $\gamma \delta$ Treg cells are enriched in tumor infiltrating lymphocytes of several types of cancer, and can not only suppress $\mathrm{T}$ cell responses and DC maturation, but also induce the immunosenescence of $\mathrm{T}$ cells 
and DCs, and further amplify Treg-mediated immunosuppression [37,38]. Human V $\gamma 9 \mathrm{~V} \delta 2 \mathrm{~T}$ cells stimulated by mycobacterium bovis bacillus Calmette-Guerin (BCG) and malaria parasite plasmodium falciparum display a memory characteristic $[39,40]$. Besides, $\mathrm{V} \gamma 9 \mathrm{~V} \delta 2 \mathrm{~T}$ cells in the presence of IL-15 and IL-21 differentiate into a memory population expressing CD45RO [41]. Whether memory $\gamma \delta \mathrm{T}$ cells have an effect against tumors still needs for further studies.

Table 1. Features of human $\gamma \delta \mathrm{T}$ cell subsets.

\begin{tabular}{cccc}
\hline Subset & Common $\mathrm{V} \gamma$ Pairs & Tissue Distribution & Anti-Tumor Effector Molecules \\
\hline \multirow{2}{*}{$\mathrm{V} \delta 1$} & $\mathrm{~V} \gamma 2, \mathrm{~V} \gamma 3, \mathrm{~V} \gamma 4, \mathrm{~V} \gamma 5$, & Skin, small intestine, & IFN- $\gamma, \mathrm{TNF}-\alpha$, Perforin, \\
& $\mathrm{V} \gamma 8, \mathrm{~V} \gamma 10$ & liver, spleen & Granzyme, TRAIL, FASL \\
$\mathrm{V} \delta 2$ & $\mathrm{~V} \gamma 9$ & Peripheral blood & IFN- $\gamma, \mathrm{TNF}-\alpha$, Perforin, \\
$\mathrm{V} \delta 3$ & Not defined & Liver, small intestine & Granzyme, TRAIL, FASL \\
$\mathrm{V} \delta 5$ & $\mathrm{~V} \gamma 4$ & Peripheral blood & Not defined \\
\hline
\end{tabular}

TRAIL: tumor necrosis factor-related apoptosis-inducing ligand; FASL: human apoptosis-related factor ligand.

\section{The Tumor Cell Recognition of $\gamma \delta$ T Cells}

\subsection{Tumor Cell Recognition of V $\gamma 9 V \delta 2 \mathrm{~T}$ Cells}

The earliest discovery is that $\mathrm{V} \gamma 9 \mathrm{~V} \delta 2 \mathrm{~T}$ cells can specifically recognize non-peptide phosphoantigen, such as IPP, with a $\gamma \delta$ TCR-dependent manner [42] (Figure 1). In normal tissues, cells synthesize isoprenoid through the mevalonate metabolism pathway to participate in the synthesis of cholesterol along with producing a small amount of IPP in the process. In order to satisfy the tumor's energy supply in the tumor tissue, the mevalonate metabolic pathway is enhanced, leading to the accumulation of IPP exceeding the normal physiological range in the cells, and thus tumor cells are recognized and killed by V $\gamma 9 \mathrm{~V} \delta 2 \mathrm{~T}$ cells [43]. F1-ATPase is generally expressed on the mitochondrial membrane, and occasionally can be expressed on liver cells and tumor cells. V $\gamma 9 \mathrm{~V} \delta 2 \mathrm{~T}$ cells can recognize tumor cells expressing Fl-ATPase, which depends on the formation of complex Fl-ATPase and apolipoprotein A-I (apo A-I) [44]. Several studies have shown that V $\gamma 9 \mathrm{~V} \delta 2 \mathrm{~T}$ cells recognize phosphoantigen depending on the butyrophilin 3A1 (BTN3A1, also known as CD277), a member of the B7 superprotein family, expressed on antigen-presenting cells (APCs) and tumor cells [45-47]. However, the molecular mechanism of the interaction between BTN3A1 and phosphoantigen is still unclear. More evidences support the hypothesis of "inside-out" triggering mechanism that BTN3A1 will undergo joint spatial and conformational changes when phosphoantigen binds to the B30.2 intracellular domain or juxtamembrane domain of BTN3A1 [47-50]. These spatial and conformational changes trigger the activation of $\mathrm{V} \gamma 9 \mathrm{~V} \delta 2 \mathrm{~T}$ cells [51]. Intriguingly, recent studies show that the other member of BTNA family, butyrophilin 2A1 (BTN2A1) is a direct ligand for V $\gamma 9 \mathrm{~V} \delta 2$ $\mathrm{TCR}$, and is essential for phosphoantigen recognition by $\mathrm{V} \gamma 9 \mathrm{~V} \delta 2 \mathrm{~T}$ cells $[52,53]$. It is revealed that BTN2A1 and BTN3A1 are co-associated on the surface of tumor cells, and are both required for phosphoantigen recognition by $\mathrm{V} \gamma 9 \mathrm{~V} \delta 2 \mathrm{~T}$ cells. After phosphoantigen binds to the B30.2 intracellular domain of BTN3A1, the BTN2A1-BTN3A1 complex engages the $\gamma \delta$ TCR via two distinct sites. BTN2A1 directly binds to the $\mathrm{V} \gamma 9$ region of $\mathrm{V} \gamma 9 \mathrm{~V} \delta 2 \mathrm{TCR}$, while BTN3A1 binds to the V $\delta 2$-encoded CDR2 and $\gamma$-chain-encoded CDR3 of V $\gamma 9 \mathrm{~V} \delta 2$ TCR $[52,53]$. These findings about the distinctive mode of phosphoantigen-dependent $\mathrm{V} \gamma 9 \mathrm{~V} \delta 2 \mathrm{~T}$ cells activation help us to better understand the recognition mechanism of $\gamma \delta$ T cells to tumors involved with phosphoantigen and facilitate attempts to develop of $\gamma \delta \mathrm{T}$ cell-based cancer immunotherapies.

In addition to the TCR-dependent way, V $\gamma 9 \mathrm{~V} \delta 2 \mathrm{~T}$ cells can recognize tumor cells through NKRs, particularly NKG2D and DNAX accessory molecule-1 (DNAM-1) (Figure 1). The NKG2D ligands currently found on human tumor cells include MHC class I chain-related molecules (MICA, MICB) and six ULBP-binding proteins (ULBP1-6) [54]. Overexpression of the ULBP1 and ULBP4 on the leukemia, lymphoma and epithelial tumors, respectively, induces cytotoxicity of $\mathrm{V} \gamma 9 \mathrm{~V} \delta 2 \mathrm{~T}$ cells to 
tumor cells [42]. In addition, DNAM-1 expressed on the V $\gamma 9 \mathrm{~V} \delta 2 \mathrm{~T}$ cells recognizes its ligands nectin-2 and polyoma virus receptor (PVR) that are widely expressed in tumor cells, which helps $\mathrm{V} \gamma 9 \mathrm{~V} \delta 2$ T cells target tumor cells $[55,56]$.

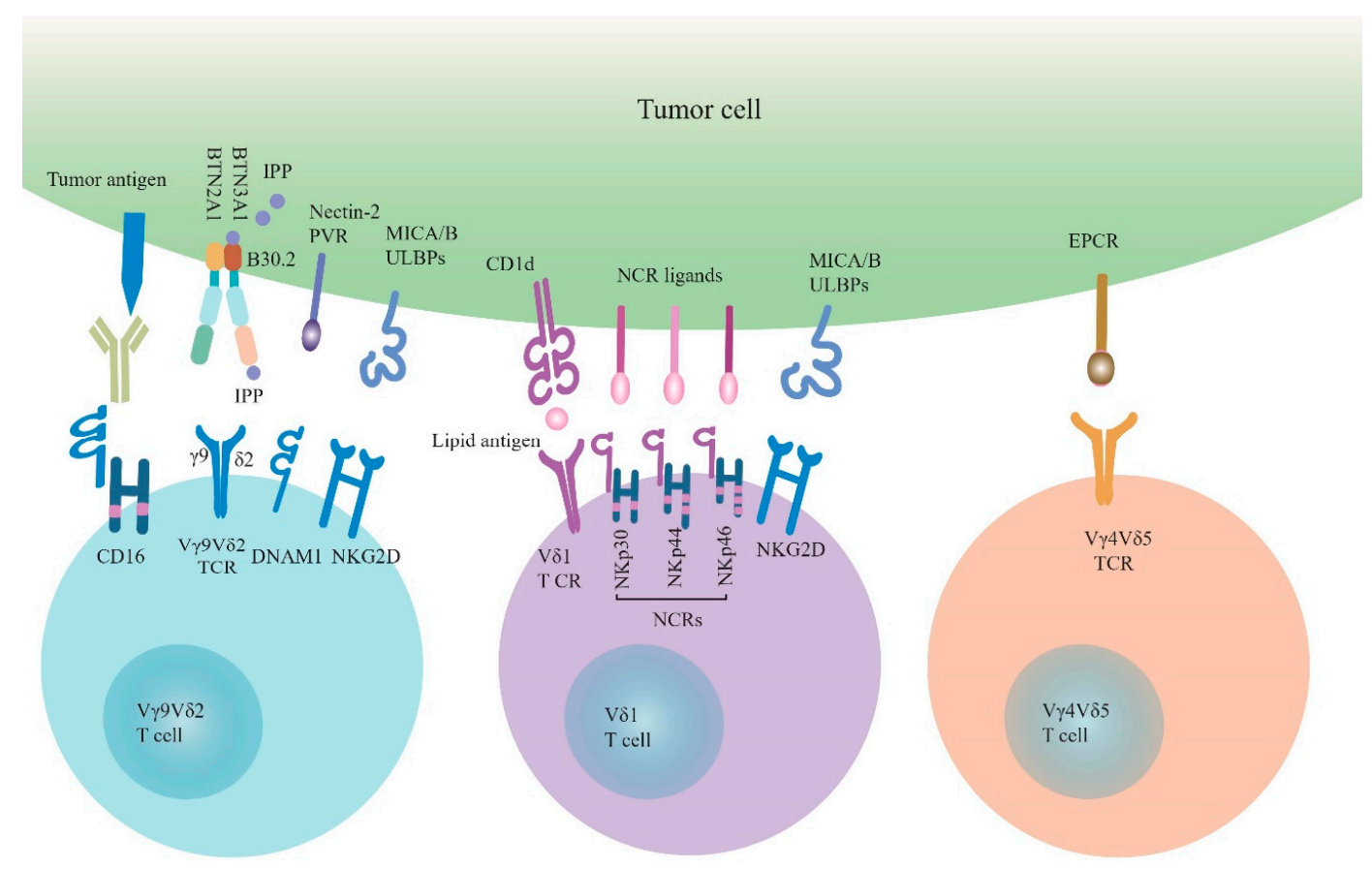

Figure 1. The tumor cell recognition of $\gamma \delta$ T cells. $\gamma \delta$ T cells recognize tumor cells through $\gamma \delta$ TCRs and NKRs. V $\gamma 9 \mathrm{~V} \delta 2$ TCR recognizes pAg (such as IPP) depending on BTN3A1 and BTN2A1. Besides, $\mathrm{V} \gamma 9 \mathrm{~V} \delta 2 \mathrm{~T}$ cells also recognize tumor cells through NKG2D and DNAM-1, which engage with their ligands (MICA/B, ULBPs and Nectin-2, PVR). V $\gamma 9 \mathrm{~V} \delta 2 \mathrm{~T}$ cells express CD16 that binds therapeutic antibodies to engage $\mathrm{V} \gamma 9 \mathrm{~V} \delta 2$-mediated ADCC. V $\delta 1 \mathrm{~T}$ cells recognize lipid antigen-presented by CD1d through V 81 TCR. NKG2D and NCRs (NKp30, NKp44, NKp46) with their ligands are involved in the tumor cell recognition by V $\delta 1 \mathrm{~T}$ cells. In addition, EPCR as a ligand of $\mathrm{V} \gamma 4 \mathrm{~V} \delta 5 \mathrm{TCR}$ is involved in the tumor cell recognition by $\mathrm{V} \gamma 4 \mathrm{~V} \delta 5 \mathrm{~T}$ cells. TCRs: $\mathrm{T}$ cell receptors; NKRs: natural killer cell receptors; pAg: phosphoantigen; IPP: isopentenyl pyrophosphate; BTN3A1: butyrophilin 3A1; BTN2A1: butyrophilin 2A1; DNAM-1: DNAX accessory molecule 1; PVR: polyoma virus receptor; MICA/B: MHC class I-related chain A/B; ULBPs: UL16-binding proteins; ADCC: antibody-dependent cell-mediated cytotoxicity; NCRs: natural cytotoxicity receptors; EPCR: endothelial protein $\mathrm{C}$ receptor.

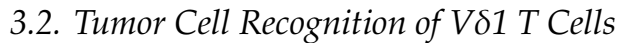

Like V $\gamma 9 \mathrm{~V} \delta 2 \mathrm{~T}$ cells, V $\delta 1 \mathrm{~T}$ cells can also recognize tumor cells in TCR-dependent and NKR-dependent ways (Figure 1). Currently, very few V 81 TCR ligands have been described. Lipid antigens-presented by CD1d, a MHC-like molecule, are reported to bind V $\delta 1 \mathrm{TCR}$, revealed by the crystal structure of V $\delta 1$ TCR in complex with CD1d-sulfatide [57-59]. Even though so far no clear evidence demonstrates that the involvement of CD1d-lipid antigens in tumor cell recognition by $\gamma \delta \mathrm{T}$ cells; however, CD1d is found to be expressed on multiple cancers, such as lymphomas, early myeloma, myeloid leukemias, medulloblastoma, and prostate cancers [60-63]. The cellular lipid composition is found to be changed during tumorigenesis, and some types of lipids, such as sulfatide, are elevated in several types of epithelial cancers [64]. Whether V $\delta 1 \mathrm{~T}$ cells may recognize specific lipid antigens presented by CD1d on the surface of tumor cells deserves further investigation. In addition, human V81 T cells can recognize MICA-expressing tumor cells by direct binding of MICA to V81 TCR [65]. However, the contribution of the V 81 TCR activation by MICA-expressing tumor cells is difficult to evaluate, because MICA also serves as a high affinity ligand for NKG2D expressed on V $\delta 1 \mathrm{~T}$ cells [13]. 
V81 T cells can also recognize tumor cells through NKRs, which have previously been thought to be unique to NK cells [10]. NKRs include NKG2D, DNAM-1 and Natural cytotoxicity receptors (NCRs), such as NKp30, NKp44 and NKp46, and other receptors. V81 T cells recognize NKG2D ligands, such as MICA/B on intestinal epithelial cells and ULBP3 expressed on B cell chronic lymphocytic leukemia (B-CLL) [66,67]. Breast-resident V $81 \mathrm{~T}$ cells are activated innately via the NKG2D receptor and are associated with the remission of triple-negative breast cancer [7]. In recent years NCR expression has been found in activated small intestinal intraepithelial lymphocytes and innate lymphoid cells (ILCs) [68]. Although V $\delta 1 \mathrm{~T}$ cells do not express NCRs under normal conditions, they can express NCRs, including NKp44, NKp30, and NKp46, under the continuous stimulation of TCR agonists in the presence of IL-15 or IL-2 [18,69]. Interestingly, this phenomenon basically appears only on V $\delta 1 \mathrm{~T}$ cells, but has not been found in $\mathrm{V} \delta 2 \mathrm{~T}$ cells [70]. These $\mathrm{NCR}^{+} \mathrm{V} \delta 1 \mathrm{~T}$ cells have a stronger anti-tumor activity against tumor cells and exert high ability to secrete IFN- $\gamma$ [71,72]. Although most ligands on tumors recognized by NCRs of V $\delta 1 \mathrm{~T}$ cells have not been characterized, B7-H6 has been reported as a ligand of NKp30 expressed on V81 T cells [73].

\subsection{Tumor Cell Recognition of $V \delta 1^{-} V \delta 2^{-} T$ Cells}

Studies about $\mathrm{V} \delta 1^{-} \mathrm{V} \delta 2^{-} \mathrm{TCR}$ ligands are rare. A previous study showed that expanded human $\mathrm{V} \delta 3 \mathrm{~T}$ cells in vitro recognize CD1d and kill CD1d ${ }^{+}$target cells [28]. A well-studied ligand of $\mathrm{V} \delta 1^{-} \mathrm{V} \delta 2^{-}$ $\mathrm{T}$ cells TCR is endothelial protein $C$ receptor (EPCR), an important component of the $C$ protein pathway, recognized by V $\gamma 4 \mathrm{~V} \delta 5$ TCR [29] (Figure 1). It belongs to MHC I/CD1-like protein molecules and can protect the endothelial barrier from hypoxia and inflammatory conditions [74]. The interaction of V $\gamma 4 \mathrm{~V} \delta 5$ TCR and EPCR may enable $\gamma \delta \mathrm{T}$ cells to recognize CMV-infected epithelial cells and epithelial tumor cells which up-regulation EPCR expression [29].

\section{Anti-Tumor Mechanism of $\gamma \delta$ T Cells}

$\gamma \delta \mathrm{T}$ cells can exert direct anti-tumor effects through a variety of pathways. Human V $\gamma 9 \mathrm{~V} \delta 2$ $\mathrm{T}$ can kill various tumor cells depending on secretion of cytotoxic substances, such as perforin and granzyme [75,76]. Besides, human V $\gamma 9 \mathrm{~V} \delta 2 \mathrm{~T}$ cells can kill osteosarcoma cells and chronic myeloid leukemia cells through the expression of tumor necrosis factor-related apoptosis-inducing ligand (TRAIL) $[76,77]$ and induce apoptosis of osteosarcoma cell lines through human apoptosis-related factor ligand (FASL) [76]. V81 T cells can also kill tumor cells by releasing perforin and granzyme, and exert TRAIL- and FASL-dependent cytotoxicity [78,79]. Similar to NK cells, human $\gamma \delta \mathrm{T}$ cells can kill tumor cells through antibody-dependent-cell-mediated cytotoxicity (ADCC) effects. CD16 ${ }^{+} \mathrm{V} \gamma 9 \mathrm{~V} \delta 2$ $\mathrm{T}$ cells can recognize monoclonal antibody coated lymphoma, chronic lymphocytic leukemia (CLL) and human epidermal growth factor receptor 2 (HER2)-positive breast cancer cells and exert anti-tumor effect via ADCC [80]. In several other studies, $\gamma \delta \mathrm{T}$ cells have also been shown to induce ADCC on target cells following treatment with antibodies $[81,82]$.

$\gamma \delta \mathrm{T}$ cells can also exert anti-tumor effects indirectly by promoting the functions of other immune cells. A unique $\mathrm{CXCR} 5^{+} \mathrm{V} \gamma 9 \mathrm{~V} \delta 2 \mathrm{~T}$ cell subset is able to express the costimulatory molecules ICOS and CD40L, and produces cytokines such as IL-2, IL-4, and IL-10, as well as helps B cells for the production of antibodies [83]. V $\gamma 9 \mathrm{~V} \delta 2 \mathrm{~T}$ cells expressing CXCL13 and CXCR5 display the characteristics of follicular helper $\mathrm{T}$ (Tfh) cells and enhance the ability of $\mathrm{B}$ cells to secrete antibodies when they are co-incubated with (E)-4-hydroxy-3-methylbut-2-enyl pyrophosphate (HMB-PP) and IL-21 in vitro [84]. No clear evidence demonstrates that human $\gamma \delta$ T cells exert anti-tumor function upon helping B cells for antibodies production, but several studies have shown that mouse $\gamma \delta \mathrm{T}$ cells can provide a protective response against tumor through providing help for B cells to class-switch to IgE production $[85,86]$. Besides, $\gamma \delta$ T cells can also serve as APCs of $\alpha \beta$ T cells and participate in the activation and proliferation of $\alpha \beta$ T cells, so that naïve $\alpha \beta$ T cells can differentiate into effector T cells and exert antitumor effects [87-89]. Furthermore, when stimulated by tumor antigens, $\gamma \delta \mathrm{T}$ cells will up-regulate the expression of antigen-presenting molecules HLA-DR, costimulatory and adhesion 
molecules $(\mathrm{CD} 80, \mathrm{CD} 86, \mathrm{CD} 40)$ and scavenger receptor $\mathrm{CD} 36$, which allow $\gamma \delta \mathrm{T}$ cells to participate in the elimination of tumor cells $[87,88]$. In addition, zoledronate-activated $\gamma \delta \mathrm{T}$ cells can improve the cytotoxicity of NK cells, which is depended on the interaction of CD137 ligand expressed on activated $\gamma \delta \mathrm{T}$ cells with CD137 expressed on NK cells [90]. $\gamma \delta \mathrm{T}$ cells can promote the maturation of DCs. In turn, DCs can also induce the activation and proliferation of $\gamma \delta \mathrm{T}$ cells, assisting directly or indirectly anti-tumor immune response of $\gamma \delta$ T cells [91,92].

\section{5. $\gamma \delta \mathrm{T}$ Cell-Based Cancer Immunotherapy}

Tumor immunotherapy restarts or enhances the anti-tumor immune response of tumor patients thereby controlling and eliminating tumors $[93,94]$. At present, there are a few tumor immunotherapies based on $\alpha \beta$ T cells, but the durability and effectiveness of the treatment need to be further improved. This is because the activation of $\alpha \beta$ T cells depends on specific tumor-associated antigens (TAA), MHC molecules, and costimulatory signals. Once TAA, MHC molecules or co-stimulatory signals lost, the tumor-killing ability of $\alpha \beta$ T cells will be reduced and even $\alpha \beta$ T cells will be disabled [95]. $\gamma \delta \mathrm{T}$ cells have no MHC restriction on tumor antigen recognition and have strong cytotoxic effects on tumor cells. Importantly, they can be easily expanded in vitro and in vivo. Therefore, $\gamma \delta \mathrm{T}$ cells have great application prospects in tumor immunotherapy. Currently, a number of clinical trials based on $\gamma \delta \mathrm{T}$ cell therapy have been finished or are ongoing to evaluate the safety and anti-tumor efficacy of $\gamma \delta \mathrm{T}$ cells (Table 2$)$.

$\mathrm{V} \gamma 9 \mathrm{~V} \delta 2 \mathrm{~T}$ cells are the most important $\gamma \delta \mathrm{T}$ cells used for immunotherapy via adoptive transfer of ex vivo-expanded $\mathrm{V} \gamma 9 \mathrm{~V} \delta 2 \mathrm{~T}$ cells or in vivo stimulation with synthetic phosphoantigens (such as BrHPP) or aminodicarbonates (N-BPs, such as zoledronate) [96]. A series of clinical trials have completed to assess the safety and efficacy of $\mathrm{V} \gamma 9 \mathrm{~V} \delta 2 \mathrm{~T}$ cells for immunotherapy (Table 2). Several studies have confirmed that $\mathrm{V} \gamma 9 \mathrm{~V} \delta 2 \mathrm{~T}$ cells can achieve specific proliferation under the stimulation of zoledronate and IL-2 $[25,97,98]$. When $\mathrm{V} \gamma 9 \mathrm{~V} \delta 2 \mathrm{~T}$ cells are applied for cancer immunotherapy, it is often accompanied by the use of BrHPP, zoledronate and IL-2 to maintain the activation status of V $\gamma 9 \mathrm{~V} \delta 2 \mathrm{~T}$ cells and increase the killing capacity to tumor cells [97-99]. Multiple clinical trials have shown that adoptive transfer of autologous $\mathrm{V} \gamma 9 \mathrm{~V} \delta 2 \mathrm{~T}$ cells is able to target diversified tumors, such as renal cell carcinoma, non-small-cell lung cancer, gastric cancer and others, and no severe toxicity is observed [98,100-106]. Six patients showed stabilized disease in ten metastatic renal cell carcinoma patients who received V $\gamma 9 \mathrm{~V} \delta 2 \mathrm{~T}$ cells transfusion [100]. Partial or complete remissions were observed in patients who were treated with autologous $\mathrm{V} \gamma 9 \mathrm{~V} \delta 2 \mathrm{~T}$ cells expanded in vitro $[98,104,106]$. In addition, allogenic $\mathrm{V} \gamma 9 \mathrm{~V} \delta 2$ $\mathrm{T}$ cells also have potential to be used in adoptive transfer immunotherapy. A patient with stage IV gallbladder cancer treated with allogenic $\mathrm{V} \gamma 9 \mathrm{~V} \delta 2 \mathrm{~T}$ cells combined with zoledronate displayed favorable results [23]. Tumor volume of the patient was reduced, importantly, the proportions of functional $\mathrm{CD}^{+}{ }^{+} \mathrm{T}$ cells and $\mathrm{CD} 8^{+} \mathrm{T}$ cells increased and exhausted $\mathrm{CD} 4^{+} \mathrm{T}$ cells and $\mathrm{CD} 8^{+} \mathrm{T}$ cells decreased after treatment with $\mathrm{V} \gamma 9 \mathrm{~V} \delta 2 \mathrm{~T}$ cells [23]. These clinical studies suggested that adoptive transfer of autologous or allogenic $\mathrm{V} \gamma 9 \mathrm{~V} \delta 2 \mathrm{~T}$ cell not only exert direct $\gamma \delta \mathrm{T}$ cell-mediated anti-tumor effect, but also promote and rescue the anti-tumor capacity of $\mathrm{CD} 4^{+}$and $\mathrm{CD} 8^{+} \mathrm{T}$ cells, suggesting a promising immunotherapeutic strategy. V $\gamma 9 \mathrm{~V} \delta 2 \mathrm{~T}$ cells stimulated with phosphoantigens or N-BPs in vivo have also shown potential to kill multiple tumor cells, but the clinical response rate is generally lower than adoptive transfer $[25,99,107-110]$. Interestingly, a recent study reported that vitamin C (VC, also known as L-ascorbic acid) and L-ascorbic acid 2-phosphate (pVC) can increase the proliferation of purified $\gamma \delta$ T cells from zoledronate- or phosphoantigen-stimulated $\gamma \delta \mathrm{T}$ cells and reduce the apoptosis of $\gamma \delta \mathrm{T}$ cells during stimulation [111]. VC may be used to enhance the efficacy and clinical response rate of immunotherapy with $\mathrm{V} \gamma 9 \mathrm{~V} \delta 2 \mathrm{~T}$ cells.

V $81 \mathrm{~T}$ cells are a subpopulation with strong antitumor activity that are expected to be used in tumor immunotherapy. They can be activated by a variety of ligands, such as stress-induced autoantigens, glycolipid antigens presented by CD1d, and various potentially undiscovered ligands [112,113]. Compared with V $\gamma 9 \mathrm{~V} \delta 2 \mathrm{~T}$ cells, V $1 \mathrm{~T}$ cells do not depend on N-BPs for their activation. Although there 
is only low proportion of V $\delta 1 \mathrm{~T}$ cells in peripheral blood, V $\delta 1 \mathrm{~T}$ cells can circulate and persist for a long time in the body, and have high tropism for tumor tissues, which is expected to maintain long-term therapeutic effects [112]. V $\delta 1 \mathrm{~T}$ cells can be largely expanded in vitro. Highly cytotoxic Delta one T (DOT) cells are V $\delta 1$-enriched $(>60 \%) \gamma \delta \mathrm{T}$ cells produced by stimulation with TCR agonists and cytokines (IL-4 and IL-15) for over 3 weeks for adoptive cell therapy [69]. A Two-step method was used for DOT cells production: in the expansion stage, sorted $\gamma \delta \mathrm{T}$ cells were stimulated with IL-4 and TCR agonists for 2 weeks, then followed a differentiation stage with an additional week of IL-15 stimulation. This method can achieve clinical-grade 2000-fold expansion within three weeks, with the percentages of $\mathrm{V} \delta 1 \mathrm{~T}$ increase from less than $0.5 \%$ to more than $70 \%$. Importantly, NCRs, particularly NKp30 and NKp44, are induced, accompanied with up-regulation of NKG2D and DNAM-1 on expanded DOT cells [69]. Of note, when the in vitro expanded DOT cells were transferred in vivo, they have ability of producing abundant IFN- $\gamma$ and TNF- $\alpha$ (but no IL-17), and displayed high capacity to inhibit tumor growth and prevent dissemination in xenograft model of CLL [69]. V81 T cells have a good therapeutic effect on a variety of lymphoid and myeloid hematomas, such as CLL and acute myeloid leukemia (AML) [69,73]. The broad cytotoxicity of DOT cells against AML strongly depended on the expression of NKp30 ligand B7-H6, while DOT cells showed no reactivity against normal leukocytes [73]. Adoptive transfer of V $\delta 1 \mathrm{~T}$ cell therapy not only reduces the tumor load in the blood and target organs of patients, but also significantly extends the survival time of patients [73]. Accordingly, V81 T cells, particularly DOT cells, may be a new candidate used for cancer immunotherapy depending on their strong anti-tumor efficacy and safety.

Table 2. $\gamma \delta$ T cell-based clinical trials.

\begin{tabular}{|c|c|c|c|c|c|}
\hline Cell Type & Interventions & Cancers & Phase & Status & $\begin{array}{c}\text { References or Study } \\
\text { Registration }\end{array}$ \\
\hline $\mathrm{V} \gamma 9 \mathrm{~V} \delta 2 \mathrm{~T}$ & $\begin{array}{l}\text { BrHPP + IL-2 } \\
\quad \text { (in vitro) }\end{array}$ & $\mathrm{RCC}$ & I & Finished & [100] \\
\hline $\mathrm{V} \gamma 9 \mathrm{~V} \delta 2 \mathrm{~T}$ & $\begin{array}{l}\text { 2M3B1PP + IL-2 } \\
\text { (in vitro) }\end{array}$ & RCC & Pilot study & Finished & [106] \\
\hline $\mathrm{V} \gamma 9 \mathrm{~V} \delta 2 \mathrm{~T}$ & $\begin{array}{l}\text { 2M3B1PP, ZOL + IL-2 } \\
\text { (in vitro) }\end{array}$ & RCC & I & Finished & [104] \\
\hline $\mathrm{V} \gamma 9 \mathrm{~V} \delta 2 \mathrm{~T}$ & ZOL + IL-2 (in vitro) & NSCLC & I & Finished & [101] \\
\hline $\mathrm{V} \gamma 9 \mathrm{~V} \delta 2 \mathrm{~T}$ & ZOL + IL-2 (in vitro) & NSCLC & I & Finished & [102] \\
\hline $\mathrm{V} \gamma 9 \mathrm{~V} \delta 2 \mathrm{~T}$ & ZOL + IL-2 (in vitro) & $\mathrm{MM}$ & I & Finished & [105] \\
\hline $\mathrm{V} \gamma 9 \mathrm{~V} \delta 2 \mathrm{~T}$ & $\mathrm{ZOL}+\mathrm{IL}-2$ (in vitro) & Gastric cancer & Pilot study & Finished & [98] \\
\hline $\mathrm{V} \gamma 9 \mathrm{~V} \delta 2 \mathrm{~T}$ & ZOL + IL-2 (in vitro) & $\begin{array}{l}\text { Metastatic solid } \\
\text { tumors }\end{array}$ & I & Finished & [103] \\
\hline $\mathrm{V} \gamma 9 \mathrm{~V} \delta 2 \mathrm{~T}$ & $\begin{array}{l}\text { Pamidronate + IL-2 } \\
\text { (in vivo) }\end{array}$ & $\mathrm{MM}$ and NHL & Pilot study & Finished & [107] \\
\hline $\mathrm{V} \gamma 9 \mathrm{~V} \delta 2 \mathrm{~T}$ & $\begin{array}{c}\text { ZOL + IL-2 } \\
\text { (in vivo) }\end{array}$ & $\begin{array}{l}\text { RCC, AML and } \\
\text { melanoma }\end{array}$ & $\mathrm{I} / \mathrm{II}$ & Finished & [108] \\
\hline $\mathrm{V} \gamma 9 \mathrm{~V} \delta 2 \mathrm{~T}$ & $\begin{array}{l}\text { BrHPP + IL-2 } \\
\quad \text { (in vivo) }\end{array}$ & $\begin{array}{l}\text { RCC, CRC and breast } \\
\text { cancer }\end{array}$ & I & Finished & [99] \\
\hline $\mathrm{V} \gamma 9 \mathrm{~V} \delta 2 \mathrm{~T}$ & ZOL + IL-2 (in vivo) & RCC & Pilot study & Finished & [109] \\
\hline $\mathrm{V} \gamma 9 \mathrm{~V} \delta 2 \mathrm{~T}$ & ZOL + IL-2 (in vivo) & Breast cancer & I & Finished & [25] \\
\hline $\mathrm{V} \gamma 9 \mathrm{~V} \delta 2 \mathrm{~T}$ & ZOL + IL-2 (in vivo) & Neuroblastoma & I & Finished & [110] \\
\hline$\gamma \delta \mathrm{T}$ & In vitro expanded & $\begin{array}{l}\text { Lymphoma and } \\
\text { leukemia }\end{array}$ & $\begin{array}{c}\text { Early phase } \\
1\end{array}$ & Recruiting & NCT04028440 \\
\hline$\gamma \delta \mathrm{T}$ & In vitro expanded & $\begin{array}{l}\text { Acute myeloid } \\
\text { leukemia }\end{array}$ & I & Recruiting & NCT04008381 \\
\hline$\gamma \delta \mathrm{T}$ & $\begin{array}{l}\text { Combined with surgery } \\
\text { (in vitro expanded) }\end{array}$ & Pancreatic cancer & I/II & Finished & NCT03180437 \\
\hline$\gamma \delta \mathrm{T}$ & $\begin{array}{l}\text { Combined with DC-CIK } \\
\text { cells (in vitro expanded) }\end{array}$ & Breast cancer & $\mathrm{I} / \mathrm{II}$ & Finished & NCT02418481 \\
\hline$\gamma \delta \mathrm{T}$ & $\begin{array}{l}\text { Combined with surgery } \\
\text { (in vitro expanded) }\end{array}$ & Breast cancer & $\mathrm{I} / \mathrm{II}$ & Finished & NCT03183206 \\
\hline$\gamma \delta \mathrm{T}$ & $\begin{array}{l}\text { Combined with DC-CIK } \\
\text { cells (in vitro expanded) }\end{array}$ & Liver cancer & $\mathrm{I} / \mathrm{II}$ & Finished & NCT02425735 \\
\hline
\end{tabular}


Table 2. Cont.

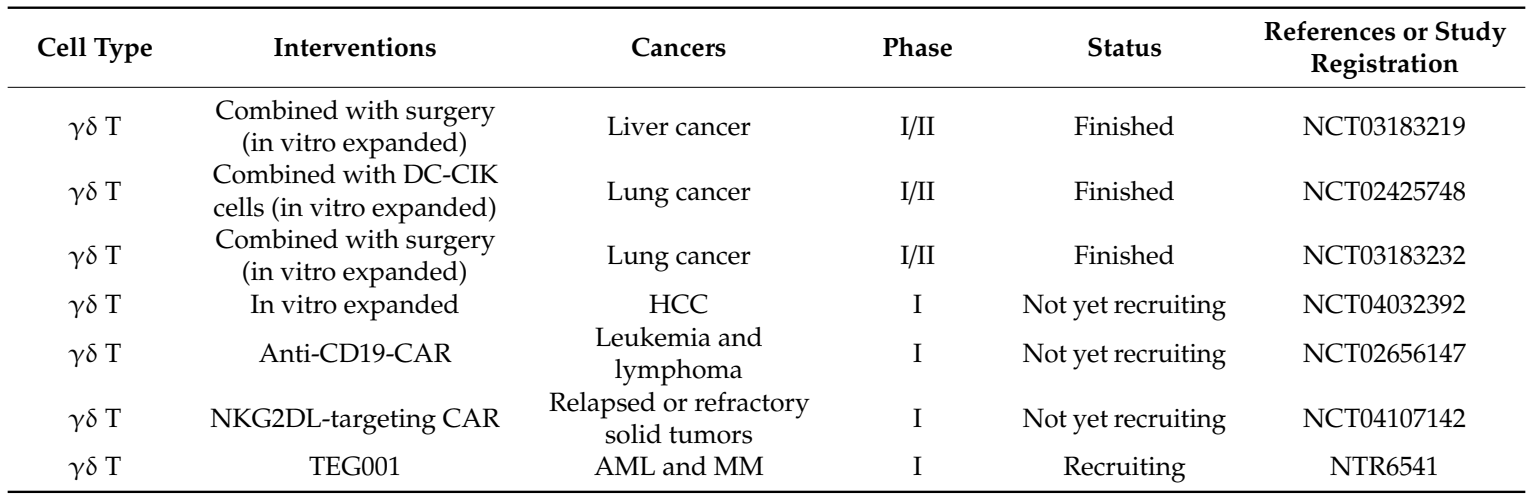

RCC: renal cell carcinoma; NSCLC: non-small-cell lung cancer; MM: multiple myeloma; HCC: hepatocellular carcinoma; NHL: non-Hodgkin's lymphoma; AML: acute myeloid leukaemia; CRC: colorectal cancer; BrHPP: bromohydrin pyrophosphate; 2M3B1PP: 2-methyl-3-butenyl-1-pyrophosphate; ZOL: zoledronate; DC-CIK cells: professional antigen- presenting dendritic cells and cytokine- induced killer cells; CAR: chimeric antigen receptor; NKG2DL: NKG2D ligand; TEG: T cells engineered with defined $\gamma \delta$ TCRs.

\section{New Strategies to Improve $\gamma \delta$ T Cell-Based Cancer Immunotherapy}

Currently, a number of novel strategies have been developed to improve the anti-tumor efficacy of $\gamma \delta$ T-based immunotherapy. Bispecific antibodies have been exploited to both facilitate the activity of $\gamma \delta \mathrm{T}$ cells and enhance the tumor-targeting. For example, bispecific antibodies targeting HER2 and $\mathrm{CD} 3$ or $\mathrm{V} \gamma 9$ chain of $\mathrm{V} \gamma 9 \mathrm{~V} \delta 2 \mathrm{TCR}$ can increase $\gamma \delta \mathrm{T}$ cells cytotoxicity against pancreatic cancer cells [114]. Adoptive transfer of $\mathrm{V} \gamma 9 \mathrm{~V} \delta 2 \mathrm{~T}$ cells with the HER2/V $\gamma 9$ bispecific antibody significantly reduced the growth of pancreatic cancer and colon cancer in mouse xenograft models $[114,115]$. In addition, bispecific antibody targeting both $\mathrm{V} \gamma 9 \mathrm{~V} \delta 2 \mathrm{TCR}$ and epidermal growth-factor receptor (EGFR) allows V $\gamma 9 \mathrm{~V} \delta 2 \mathrm{~T}$ cells accumulation and activation specifically at the tumor sites, and kills tumor cells in vitro and in mouse xenograft model [116]. Furthermore, a (HER2)2xCD16 tribody form, which comprises two HER2-specific single chain fragment variable fused to a fragment antigen binding to the CD16 expressed on $\gamma \delta \mathrm{T}$ or NK cells, enhanced the anti-tumor activity of $\gamma \delta \mathrm{T}$ and NK cells against HER2-expressing tumors, including pancreatic cancer, breast cancer and ovarian cancer [117]. Thus, bispecific antibodies may represent an attractive strategy to enhance anti-tumor cytotoxicity of $\gamma \delta \mathrm{T}$ cells.

In recent years, CAR-T cells have made great progress in the treatment of acute leukemia and non-Hodgkin's lymphoma. Therefore, CAR-T cells are considered to be one of the most promising tumor immunotherapies [118]. However, CAR-T cell immunotherapy still has some problems in the clinical application, such as cytokine storm, off-target effect, poor effect on solid tumors and a high recurrence rate after treatment [119]. Due to the unique ability of $\gamma \delta \mathrm{T}$ cells to recognize tumors, people have begun to consider whether CAR- $\gamma \delta \mathrm{T}$ cells can become another effector cells with great potential for tumor adoptive cell immunotherapy [120]. Previous study has confirmed that targeting CD19 of CAR- $\gamma \delta \mathrm{T}$ cells have significantly improved the cytotoxicity of CD19 ${ }^{+}$tumor cells in vitro and in vivo, indicating that CAR $-\gamma \delta$ T cells are expected to be used to tumor immunotherapy [121]. GD2 is a ganglioside that is widely expressed on the surface of neuroblastoma cells and several other cancer types. Targeting GD2 CAR- $\gamma \delta$ T cells are designed in order to limit the toxic and side effects of CAR- $\gamma \delta$ T cells [122]. In this design, the activation of CAR- $\gamma \delta \mathrm{T}$ cells requires two independent signals. $\gamma \delta \mathrm{TCR}$ recognizes the tumor antigen as the first signal. Then the monoclonal antibody against GD2 recognizes GD2 and activates the downstream co-stimulation signal domain to provide a second signal. CAR- $\gamma \delta$ $\mathrm{T}$ cells can be activated to exert antitumor effects with the simultaneous participation of these two signals [122]. Since normal cells will not be recognized by $\gamma \delta$ T cells, modified GD2-targeting CAR- $\gamma \delta$ $\mathrm{T}$ cells do not have cytotoxicity to normal tissues. Other study also showed that their constructed GD2-targeted CAR- $\gamma \delta$ T cells can maintain the ability to migrate to tumor sites and tumor cell-specific 
cytotoxicity [123]. CD19-targeting CAR- $\gamma \delta \mathrm{T}$ cells are being developed for the treatment of lymphoma and leukemia in an ongoing clinical trial. A clinical trial of NKG2D ligand-targeting CAR- $\gamma \delta$ T cells is being implemented for the treatment of relapsed or refractory solid tumors (Table 2). CAR- $\gamma \delta \mathrm{T}$ cells are expected to become a new type of tumor immunotherapy in the future.

A new type of CAR-T cells, named T cells engineered with defined $\gamma \delta$ TCRs (TEGs), has recently produced by transducing high-affinity $\mathrm{V} \gamma 9 \mathrm{~V} \delta 2 \mathrm{TCR}$ into $\alpha \beta \mathrm{T}$ cells $[124,125]$. This strategy combines the advantages of $\gamma \delta \mathrm{T}$ cells that target tumors through $\mathrm{V} \gamma 9 \mathrm{~V} \delta 2 \mathrm{TCR}$ and retains ability of high proliferation, with the memory features of conventional $\alpha \beta$ T cells. Therefore, TEGs can target a large broad of tumor cells based on the broad reactivity of V $\gamma 9 \mathrm{~V} \delta 2 \mathrm{TCR}$, and can overcome the low persistence and impaired activation of $\gamma \delta \mathrm{T}$ cells in tumor microenvironment $[12,13]$. It is reported that TEG exhibits highly cytotoxicity against both haematological and solid tumors, including leukemia stem cells $[125,126]$. Currently, TEGs product has been produced under GMP conditions and are being used in a Phase I clinical trials for treatment of patients with relapsed and refractory AML and multiple myeloma (NTR6541) [127].

Checkpoint inhibitors, particularly anti-cytotoxic T lymphocyte antigen 4 (CTLA-4) and antiprogrammed cell death 1 (PD-1)/programmed cell death-ligand (PD-L1) antibodies, have shown promising clinical efficacy in treatment of multiple tumors [128-131]. Several studies have found that V $\gamma 9 \mathrm{~V} \delta 2 \mathrm{~T}$ cells express some inhibitory receptors (such as PD-1 and TIM-3) [132,133]. The presence of TIM-3 suppress the killing efficacy of $\mathrm{V} \gamma 9 \mathrm{~V} \delta 2 \mathrm{~T}$ cells by inhibiting the expression of perforin and granzyme B [132]. Blocking PD-1 and TIM-3 can rescue the anti-tumor activity of V $\gamma 9 \mathrm{~V} \delta 2 \mathrm{~T}$ cells. Moreover, PD-1 blockade boosts $\gamma \delta$ T cell-mediated ADCC in follicular lymphoma [133]. Combination therapy with adoptive transfer of $\gamma \delta \mathrm{T}$ cells and checkpoint receptor blockade could be a new strategy for $\gamma \delta \mathrm{T}$ cell-based cancer immunotherapy.

\section{Conclusions and Perspectives}

The anti-tumor effects of $\gamma \delta \mathrm{T}$ cells and their great potentiality for tumor immunotherapy have gradually attracted more and more attention. Because $\gamma \delta \mathrm{T}$ cells have no MHC restriction for tumor antigen recognition, $\gamma \delta \mathrm{T}$ cells-based tumor immunotherapy may be able to avoid immune escape caused by down-regulation of MHC class I molecules and also avoid the graft-versus-host effects (GVHD) of MHC-mismatched $\alpha \beta$ T cells [12,134]. It is suggested that $\gamma \delta \mathrm{T}$ cells might be particularly suited for the therapy of tumors with low mutational burdens, where immune checkpoint inhibition is usually unsuccessful. $\gamma \delta \mathrm{T}$ cells have the potential to become emerging allogeneic cell therapy products in the future. However, there are still some problems in using $\gamma \delta \mathrm{T}$ cells for the clinical application. One of the problems is the low response rate of treatment of $\mathrm{V} \gamma 9 \mathrm{~V} \delta 2 \mathrm{~T}$ in clinal trails. Engineered $\gamma \delta \mathrm{T}$ cells (such as CAR- $\gamma \delta \mathrm{T}$ cells and TEGs) or in combination with checkpoint inhibitors may improve the response rate of $\gamma \delta \mathrm{T}$ cell therapy and have a better anti-tumor efficacy. New methods or techniques need to be established to achieve effective expansion of $\mathrm{V} \gamma 9 \mathrm{~V} \delta 2 \mathrm{~T}$ cells and $\mathrm{V} \delta 1 \mathrm{~T}$ cells. Although $\mathrm{V} \gamma 9 \mathrm{~V} \delta 2 \mathrm{~T}$ cells activated by zoledronate and low-dose IL-2 are confirmed to be safe and well tolerated, the clinical outcomes are limited [25]. Other cytokines, such as IL-15, may be superior to IL-2 for the activation and persistence of V $\gamma 9 \mathrm{~V} \delta 2 \mathrm{~T}$ cells in vivo $[135,136]$. Currently, the major of clinical trials only focus on autologous $\gamma \delta \mathrm{T}$ cells, development of allogenic off-the-shelf $\gamma \delta \mathrm{T}$ cells are needed and feasible because the unique features of $\gamma \delta \mathrm{T}$ cells, such as non-MHC restriction and no risk of GVHD. Besides, the mechanism of tumor-associated antigens or ligands recognized by $\gamma \delta \mathrm{T}$ cells via their TCRs or NKRs needs to be further understood, which may help us find some new targets for tumor immunotherapy.

Author Contributions: Y.L. and C.Z., organizing the content of manuscript and writing. All authors have read and agreed to the published version of the manuscript.

Funding: This work was supported by grants from the National Natural Science Foundation of China (91842305, 81771686), the Shandong Provincial Key Research and Development Program (Major Scientific and Technological 
Innovation Project) (2019JZZY021013), and the National Major Science \& Technology Project for Control and Prevention of Major Infectious Diseases in China (2018ZX10301401).

Conflicts of Interest: The authors declare no conflict of interest.

\section{References}

1. Carding, S.R.; Egan, P.J. Gammadelta T cells: Functional plasticity and heterogeneity. Nat. Rev. Immunol. 2002, 2, 336-345. [CrossRef] [PubMed]

2. Chien, Y.H.; Meyer, C.; Bonneville, M. gammadelta T cells: First line of defense and beyond. Annu. Rev. Immunol. 2014, 32, 121-155. [CrossRef] [PubMed]

3. Poggi, A.; Zocchi, M.R. $\gamma \delta$ T Lymphocytes as a First Line of Immune Defense: Old and New Ways of Antigen Recognition and Implications for Cancer Immunotherapy. Front. Immunol. 2014, 5, 575. [CrossRef] [PubMed]

4. Holtmeier, W.; Kabelitz, D. gammadelta $\mathrm{T}$ cells link innate and adaptive immune responses. Chem. Immunol. Allergy 2005, 86, 151-183. [PubMed]

5. Bonneville, M.; O’Brien, R.L.; Born, W.K. Gammadelta T cell effector functions: A blend of innate programming and acquired plasticity. Nat. Rev. Immunol. 2010, 10,467-478. [CrossRef]

6. Chitadze, G.; Oberg, H.-H.; Wesch, D.; Kabelitz, D. The Ambiguous Role of $\gamma \delta$ T Lymphocytes in Antitumor Immunity. Trends Immunol. 2017, 38, 668-678. [CrossRef]

7. Wu, Y.; Kyle-Cezar, F.; Woolf, R.T.; Naceur-Lombardelli, C.; Owen, J.; Biswas, D.; Lorenc, A.; Vantourout, P.; Gazinska, P.; Grigoriadis, A.; et al. An innate-like V $\delta 1 \gamma \delta \mathrm{T}$ cell compartment in the human breast is associated with remission in triple-negative breast cancer. Sci. Transl. Med. 2019, 11. [CrossRef]

8. Devaud, C.; Rousseau, B.; Netzer, S.; Pitard, V.; Paroissin, C.; Khairallah, C.; Costet, P.; Moreau, J.-F.; Couillaud, F.; Dechanet-Merville, J.; et al. Anti-metastatic potential of human V $\delta 1(+) \gamma \delta \mathrm{T}$ cells in an orthotopic mouse xenograft model of colon carcinoma. Cancer Immunol. Immunother. 2013, 62, 1199-1210. [CrossRef]

9. Kakimi, K.; Matsushita, H.; Murakawa, T.; Nakajima, J. $\gamma \delta$ T cell therapy for the treatment of non-small cell lung cancer. Transl. Lung Cancer Res. 2014, 3, $23-33$.

10. Correia, D.V.; Lopes, A.; Silva-Santos, B. Tumor cell recognition by $\gamma \delta \mathrm{T}$ lymphocytes: T-cell receptor vs. NK-cell receptors. Oncoimmunology 2013, 2, e22892. [CrossRef]

11. Lafont, V.; Sanchez, F.; Laprevotte, E.; Michaud, H.-A.; Gros, L.; Eliaou, J.-F.; Bonnefoy, N. Plasticity of $\gamma \delta$ T Cells: Impact on the Anti-Tumor Response. Front. Immunol. 2014, 5, 622. [CrossRef] [PubMed]

12. Silva-Santos, B.; Mensurado, S.; Coffelt, S.B. gammadelta T cells: Pleiotropic immune effectors with therapeutic potential in cancer. Nat. Rev. Cancer 2019, 19, 392-404. [CrossRef] [PubMed]

13. Sebestyen, Z.; Prinz, I.; Déchanet-Merville, J.; Silva-Santos, B.; Kuball, J. Translating gammadelta $(\gamma \delta)$ T cells and their receptors into cancer cell therapies. Nat. Rev. Drug Discov. 2020, 19, 169-184. [CrossRef]

14. Lee, H.W.; Chung, Y.S.; Kim, T.J. Heterogeneity of Human $\gamma \delta$ T Cells and Their Role in Cancer Immunity. Immune Netw. 2020, 20, e5. [CrossRef] [PubMed]

15. Sullivan, L.C.; Shaw, E.M.; Stankovic, S.; Snell, G.I.; Brooks, A.G.; Westall, G.P. The complex existence of $\gamma \delta$ T cells following transplantation: The good, the bad and the simply confusing. Clin. Transl. Immunol. 2019, 8, e1078. [CrossRef]

16. Fichtner, A.S.; Ravens, S.; Prinz, I. Human $\gamma \delta$ TCR Repertoires in Health and Disease. Cells 2020, 9, 800. [CrossRef]

17. Pang, D.J.; Neves, J.F.; Sumaria, N.; Pennington, D.J. Understanding the complexity of $\gamma \delta$ T-cell subsets in mouse and human. Immunology 2012, 136, 283-290. [CrossRef]

18. Mikulak, J.; Oriolo, F.; Bruni, E.; Roberto, A.; Colombo, F.S.; Villa, A.; Bosticardo, M.; Bortolomai, I.; Lo Presti, E.; Meraviglia, S.; et al. NKp46-expressing human gut-resident intraepithelial V $\delta 1 \mathrm{~T}$ cell subpopulation exhibits high antitumor activity against colorectal cancer. Jci Insight 2019, 4. [CrossRef]

19. Zhao, Y.; Niu, C.; Cui, J. Gamma-delta (gammadelta) T cells: Friend or foe in cancer development? J. Transl. Med. 2018, 16, 3. [CrossRef]

20. Sant, S.; Jenkins, M.R.; Dash, P.; Watson, K.A.; Wang, Z.; Pizzolla, A.; Koutsakos, M.; Nguyen, T.H.; Lappas, M.; Crowe, J.; et al. Human $\gamma \delta$ T-cell receptor repertoire is shaped by influenza viruses, age and tissue compartmentalisation. Clin. Transl. Immunol. 2019, 8, e1079. [CrossRef] 
21. Siegers, G.M.; Dhamko, H.; Wang, X.-H.; Mathieson, A.M.; Kosaka, Y.; Felizardo, T.C.; Medin, J.A.; Tohda, S.; Schueler, J.; Fisch, P.; et al. Human V $\delta 1 \gamma \delta$ T cells expanded from peripheral blood exhibit specific cytotoxicity against B-cell chronic lymphocytic leukemia-derived cells. Cytotherapy 2011, 13, 753-764. [CrossRef] [PubMed]

22. Knight, A.; Mackinnon, S.; Lowdell, M.W. Human Vdelta1 gamma-delta T cells exert potent specific cytotoxicity against primary multiple myeloma cells. Cytotherapy 2012, 14, 1110-1118. [CrossRef] [PubMed]

23. Alnaggar, M.; Xu, Y.; Li, J.; He, J.; Chen, J.; Li, M.; Wu, Q.; Lin, L.; Liang, Y.; Wang, X.; et al. Allogenic $\mathrm{V} \gamma 9 \mathrm{~V} \delta 2 \mathrm{~T}$ cell as new potential immunotherapy drug for solid tumor: A case study for cholangiocarcinoma. J. Immunother. Cancer 2019, 7, 36. [CrossRef] [PubMed]

24. Joalland, N.; Chauvin, C.; Oliver, L.; Vallette, F.M.; Pecqueur, C.; Jarry, U.; Scotet, E. IL-21 Increases the Reactivity of Allogeneic Human V $\gamma 9$ V $\delta 2$ T Cells Against Primary Glioblastoma Tumors. J. Immunother. 2018, 41, 224-231. [CrossRef]

25. Meraviglia, S.; Eberl, M.; Vermijlen, D.; Todaro, M.; Buccheri, S.; Cicero, G.; La Mendola, C.; Guggino, G.; D'Asaro, M.; Orlando, V.; et al. In vivo manipulation of Vgamma9Vdelta2 T cells with zoledronate and low-dose interleukin-2 for immunotherapy of advanced breast cancer patients. Clin. Exp. Immunol. 2010, 161, 290-297.

26. Di Carlo, E.; Bocca, P.; Emionite, L.; Cilli, M.; Cipollone, G.; Morandi, F.; Raffaghello, L.; Pistoia, V.; Prigione, I. Mechanisms of the antitumor activity of human $\mathrm{V} \gamma 9 \mathrm{~V} \delta 2 \mathrm{~T}$ cells in combination with zoledronic acid in a preclinical model of neuroblastoma. Mol. Ther. 2013, 21, 1034-1043. [CrossRef]

27. Davey, M.S.; Willcox, C.R.; Hunter, S.; Kasatskaya, S.A.; Remmerswaal, E.B.M.; Salim, M.; Mohammed, F.; Bemelman, F.J.; Chudakov, D.M.; Oo, Y.H.; et al. The human V 22 T-cell compartment comprises distinct innate-like V $\gamma 9$ and adaptive V $\gamma 9$ subsets. Nat. Commun. 2018, 9, 1760. [CrossRef] [PubMed]

28. Mangan, B.A.; Dunne, M.R.; O’Reilly, V.P.; Dunne, P.J.; Exley, M.A.; O'Shea, D.; Scotet, E.; Hogan, A.E.; Doherty, D.G. Cutting edge: CD1d restriction and Th1/Th2/Th17 cytokine secretion by human V $83 \mathrm{~T}$ cells. J. Immunother. 2013, 191, 30-34. [CrossRef]

29. Willcox, C.R.; Pitard, V.; Netzer, S.; Couzi, L.; Salim, M.; Silberzahn, T.; Moreau, J.-F.; Hayday, A.C.; Willcox, B.E.; Déchanet-Merville, J. Cytomegalovirus and tumor stress surveillance by binding of a human $\gamma \delta \mathrm{T}$ cell antigen receptor to endothelial protein C receptor. Nat. Immunol. 2012, 13, 872-879. [CrossRef]

30. Qin, G.; Liu, Y.; Zheng, J.; Xiang, Z.; Ng, I.H.Y.; Malik Peiris, J.S.; Lau, Y.-L.; Tu, W. Phenotypic and functional characterization of human $\gamma \delta$ T-cell subsets in response to influenza A viruses. J. Infect. Dis. 2012, 205, 1646-1653. [CrossRef]

31. Chen, H.; He, W. Human regulatory $\gamma \delta$ T cells and their functional plasticity in the tumor microenvironment. Cell. Mol. Immunol. 2018, 15, 411-413. [CrossRef]

32. Wesch, D.; Glatzel, A.; Kabelitz, D. Differentiation of resting human peripheral blood gamma delta T cells toward Th1- or Th2-phenotype. Cell. Immunol. 2001, 212, 110-117. [CrossRef]

33. McGeachy, M.J.; Cua, D.J.; Gaffen, S.L. The IL-17 Family of Cytokines in Health and Disease. Immunity 2019, 50, 892-906. [CrossRef]

34. Caccamo, N.; La Mendola, C.; Orlando, V.; Meraviglia, S.; Todaro, M.; Stassi, G.; Sireci, G.; Fournié, J.J.; Dieli, F. Differentiation, phenotype, and function of interleukin-17-producing human V $\gamma 9 \mathrm{~V} \delta 2 \mathrm{~T}$ cells. Blood 2011, 118, 129-138. [CrossRef] [PubMed]

35. Ness-Schwickerath, K.J.; Jin, C.; Morita, C.T. Cytokine requirements for the differentiation and expansion of IL-17A- and IL-22-producing human Vgamma2Vdelta2 T cells. J. Immunother. 2010, 184, 7268-7280.

36. Mou, W.; Han, W.; Ma, X.; Wang, X.; Qin, H.; Zhao, W.; Ren, X.; Chen, X.; Yang, W.; Cheng, H.; et al. $\gamma \delta T F H$ cells promote $\mathrm{B}$ cell maturation and antibody production in neuroblastoma. BMC Immunol. 2017, 18, 36. [CrossRef] [PubMed]

37. Ye, J.; Ma, C.; Hsueh, E.C.; Eickhoff, C.S.; Zhang, Y.; Varvares, M.A.; Hoft, D.F.; Peng, G. Tumor-derived $\gamma \delta$ regulatory $\mathrm{T}$ cells suppress innate and adaptive immunity through the induction of immunosenescence. J. Immunother. 2013, 190, 2403-2414. [CrossRef] [PubMed]

38. Peng, G.; Wang, H.Y.; Peng, W.; Kiniwa, Y.; Seo, K.H.; Wang, R.-F. Tumor-infiltrating gammadelta T cells suppress $\mathrm{T}$ and dendritic cell function via mechanisms controlled by a unique toll-like receptor signaling pathway. Immunity 2007, 27, 334-348. [CrossRef] 
39. Teirlinck, A.C.; McCall, M.B.B.; Roestenberg, M.; Scholzen, A.; Woestenenk, R.; de Mast, Q.; van der Ven, A.J.A.M.; Hermsen, C.C.; Luty, A.J.F.; Sauerwein, R.W. Longevity and composition of cellular immune responses following experimental Plasmodium falciparum malaria infection in humans. PLoS Pathog. 2011, 7, e1002389. [CrossRef]

40. Hoft, D.F.; Brown, R.M.; Roodman, S.T. Bacille Calmette-Guerin vaccination enhances human gamma delta $\mathrm{T}$ cell responsiveness to mycobacteria suggestive of a memory-like phenotype. J. Immunol. 1998, 161, 1045-1054.

41. Eberl, M.; Engel, R.; Beck, E.; Jomaa, H. Differentiation of human gamma-delta T cells towards distinct memory phenotypes. Cell. Immunol. 2002, 218,1-6. [CrossRef]

42. Silva-Santos, B.; Serre, K.; Norell, H. $\gamma \delta$ T cells in cancer. Nat. Rev. Immunol. 2015, 15, 683-691. [CrossRef] [PubMed]

43. Mullen, P.J.; Yu, R.; Longo, J.; Archer, M.C.; Penn, L.Z. The interplay between cell signalling and the mevalonate pathway in cancer. Nat. Rev. Cancer 2016, 16, 718-731. [CrossRef] [PubMed]

44. Scotet, E.; Martinez, L.O.; Grant, E.; Barbaras, R.; Jenö, P.; Guiraud, M.; Monsarrat, B.; Saulquin, X.; Maillet, S.; Estève, J.-P.; et al. Tumor recognition following Vgamma9Vdelta2 $\mathrm{T}$ cell receptor interactions with a surface F1-ATPase-related structure and apolipoprotein A-I. Immunity 2005, 22, 71-80. [CrossRef] [PubMed]

45. Vavassori, S.; Kumar, A.; Wan, G.S.; Ramanjaneyulu, G.S.; Cavallari, M.; El Daker, S.; Beddoe, T.; Theodossis, A.; Williams, N.K.; Gostick, E.; et al. Butyrophilin 3A1 binds phosphorylated antigens and stimulates human $\gamma \delta$ T cells. Nat. Immunol. 2013, 14, 908-916. [CrossRef]

46. Kabelitz, D. CD277 takes the lead in human $\gamma \delta$ T-cell activation. Blood 2012, 120, 2159-2161. [CrossRef]

47. Sandstrom, A.; Peigné, C.-M.; Léger, A.; Crooks, J.E.; Konczak, F.; Gesnel, M.-C.; Breathnach, R.; Bonneville, M.; Scotet, E.; Adams, E.J. The intracellular B30.2 domain of butyrophilin 3A1 binds phosphoantigens to mediate activation of human V $\gamma 9 \mathrm{~V} \delta 2 \mathrm{~T}$ cells. Immunity 2014, 40, 490-500. [CrossRef]

48. Nguyen, K.; Li, J.; Puthenveetil, R.; Lin, X.; Poe, M.M.; Hsiao, C.-H.C.; Vinogradova, O.; Wiemer, A.J. The butyrophilin 3A1 intracellular domain undergoes a conformational change involving the juxtamembrane region. FASEB J. 2017, 31, 4697-4706. [CrossRef]

49. Yang, Y.; Li, L.; Yuan, L.; Zhou, X.; Duan, J.; Xiao, H.; Cai, N.; Han, S.; Ma, X.; Liu, W.; et al. A Structural Change in Butyrophilin upon Phosphoantigen Binding Underlies Phosphoantigen-Mediated V $\gamma 9$ V $\delta 2$ T Cell Activation. Immunity 2019, 50. [CrossRef]

50. Peigné, C.-M.; Léger, A.; Gesnel, M.-C.; Konczak, F.; Olive, D.; Bonneville, M.; Breathnach, R.; Scotet, E. The Juxtamembrane Domain of Butyrophilin BTN3A1 Controls Phosphoantigen-Mediated Activation of Human V $\gamma 9$ V 82 T Cells. J. Immunother. 2017, 198, 4228-4234. [CrossRef]

51. Gu, S.; Sachleben, J.R.; Boughter, C.T.; Nawrocka, W.I.; Borowska, M.T.; Tarrasch, J.T.; Skiniotis, G.; Roux, B.; Adams, E.J. Phosphoantigen-induced conformational change of butyrophilin 3A1 (BTN3A1) and its implication on V $\gamma 9$ V82 T cell activation. Proc. Natl. Acad. Sci. USA 2017, 114, E7311-E7320. [CrossRef]

52. Karunakaran, M.M.; Willcox, C.R.; Salim, M.; Paletta, D.; Fichtner, A.S.; Noll, A.; Starick, L.; Nöhren, A.; Begley, C.R.; Berwick, K.A.; et al. Butyrophilin-2A1 Directly Binds Germline-Encoded Regions of the V $\gamma 9 \mathrm{~V} \delta 2$ TCR and Is Essential for Phosphoantigen Sensing. Immunity 2020, 52. [CrossRef] [PubMed]

53. Rigau, M.; Ostrouska, S.; Fulford, T.S.; Johnson, D.N.; Woods, K.; Ruan, Z.; McWilliam, H.E.G.; Hudson, C.; Tutuka, C.; Wheatley, A.K.; et al. Butyrophilin 2A1 is essential for phosphoantigen reactivity by $\gamma \delta \mathrm{T}$ cells. Science 2020, 367. [CrossRef] [PubMed]

54. Dhar, P.; Wu, J.D. NKG2D and its ligands in cancer. Curr. Opin. Immunol. 2018, 51, 55-61. [CrossRef] [PubMed]

55. Toutirais, O.; Cabillic, F.; Le Friec, G.; Salot, S.; Loyer, P.; Le Gallo, M.; Desille, M.; de La Pintière, C.T.; Daniel, P.; Bouet, F.; et al. DNAX accessory molecule-1 (CD226) promotes human hepatocellular carcinoma cell lysis by Vgamma9Vdelta2 T cells. Eur. J. Immunol. 2009, 39, 1361-1368. [CrossRef]

56. Gertner-Dardenne, J.; Castellano, R.; Mamessier, E.; Garbit, S.; Kochbati, E.; Etienne, A.; Charbonnier, A.; Collette, Y.; Vey, N.; Olive, D. Human V $\gamma 9 \mathrm{~V} \delta 2 \mathrm{~T}$ cells specifically recognize and kill acute myeloid leukemic blasts. J. Immunother. 2012, 188, 4701-4708. [CrossRef]

57. Luoma, A.M.; Castro, C.D.; Adams, E.J. $\gamma \delta$ T cell surveillance via CD1 molecules. Trends Immunol. 2014, 35, 613-621. [CrossRef] 
58. Bai, L.; Picard, D.; Anderson, B.; Chaudhary, V.; Luoma, A.; Jabri, B.; Adams, E.J.; Savage, P.B.; Bendelac, A. The majority of CD1d-sulfatide-specific T cells in human blood use a semiinvariant V 11 TCR. Eur. J. Immunol. 2012, 42, 2505-2510. [CrossRef]

59. Luoma, A.M.; Castro, C.D.; Mayassi, T.; Bembinster, L.A.; Bai, L.; Picard, D.; Anderson, B.; Scharf, L.; Kung, J.E.; Sibener, L.V.; et al. Crystal structure of V $\delta 1 \mathrm{~T}$ cell receptor in complex with CD1d-sulfatide shows MHC-like recognition of a self-lipid by human $\gamma \delta$ T cells. Immunity 2013, 39, 1032-1042. [CrossRef]

60. Dhodapkar, M.V.; Geller, M.D.; Chang, D.H.; Shimizu, K.; Fujii, S.-I.; Dhodapkar, K.M.; Krasovsky, J. A reversible defect in natural killer $\mathrm{T}$ cell function characterizes the progression of premalignant to malignant multiple myeloma. J. Exp. Med. 2003, 197, 1667-1676. [CrossRef]

61. Dhodapkar, M.V.; Richter, J. Harnessing natural killer T (NKT) cells in human myeloma: Progress and challenges. Clin. Immunol. 2011, 140, 160-166. [CrossRef] [PubMed]

62. Liu, D.; Song, L.; Brawley, V.S.; Robison, N.; Wei, J.; Gao, X.; Tian, G.; Margol, A.; Ahmed, N.; Asgharzadeh, S.; et al. Medulloblastoma expresses CD1d and can be targeted for immunotherapy with NKT cells. Clin. Immunol. 2013, 149, 55-64. [CrossRef] [PubMed]

63. Nowak, M.; Arredouani, M.S.; Tun-Kyi, A.; Schmidt-Wolf, I.; Sanda, M.G.; Balk, S.P.; Exley, M.A. Defective NKT cell activation by CD1d+ TRAMP prostate tumor cells is corrected by interleukin-12 with $\alpha$-galactosylceramide. PLoS ONE 2010, 5, e11311. [CrossRef] [PubMed]

64. Liu, Y.; Chen, Y.; Momin, A.; Shaner, R.; Wang, E.; Bowen, N.J.; Matyunina, L.V.; Walker, L.D.; McDonald, J.F.; Sullards, M.C.; et al. Elevation of sulfatides in ovarian cancer: An integrated transcriptomic and lipidomic analysis including tissue-imaging mass spectrometry. Mol. Cancer 2010, 9, 186. [CrossRef]

65. Xu, B.; Pizarro, J.C.; Holmes, M.A.; McBeth, C.; Groh, V.; Spies, T.; Strong, R.K. Crystal structure of a gammadelta T-cell receptor specific for the human MHC class I homolog MICA. Proc. Natl. Acad. Sci. USA 2011, 108, 2414-2419. [CrossRef]

66. Poggi, A.; Venturino, C.; Catellani, S.; Clavio, M.; Miglino, M.; Gobbi, M.; Steinle, A.; Ghia, P.; Stella, S.; Caligaris-Cappio, F.; et al. Vdelta1 T lymphocytes from B-CLL patients recognize ULBP3 expressed on leukemic B cells and up-regulated by trans-retinoic acid. Cancer Res. 2004, 64, 9172-9179. [CrossRef]

67. Groh, V.; Steinle, A.; Bauer, S.; Spies, T. Recognition of stress-induced MHC molecules by intestinal epithelial gammadelta T cells. Science 1998, 279, 1737-1740. [CrossRef]

68. Satoh-Takayama, N.; Vosshenrich, C.A.J.; Lesjean-Pottier, S.; Sawa, S.; Lochner, M.; Rattis, F.; Mention, J.-J.; Thiam, K.; Cerf-Bensussan, N.; Mandelboim, O.; et al. Microbial flora drives interleukin 22 production in intestinal NKp46+ cells that provide innate mucosal immune defense. Immunity 2008, 29, 958-970. [CrossRef]

69. Almeida, A.R.; Correia, D.V.; Fernandes-Platzgummer, A.; da Silva, C.L.; da Silva, M.G.; Anjos, D.R.; Silva-Santos, B. Delta One T Cells for Immunotherapy of Chronic Lymphocytic Leukemia: Clinical-Grade Expansion/Differentiation and Preclinical Proof of Concept. Clin. Cancer Res. 2016, 22, 5795-5804. [CrossRef]

70. Correia, D.V.; Fogli, M.; Hudspeth, K.; da Silva, M.G.; Mavilio, D.; Silva-Santos, B. Differentiation of human peripheral blood V $81+\mathrm{T}$ cells expressing the natural cytotoxicity receptor NKp30 for recognition of lymphoid leukemia cells. Blood 2011, 118. [CrossRef]

71. Silva-Santos, B.; Strid, J. Working in "NK Mode": Natural Killer Group 2 Member D and Natural Cytotoxicity Receptors in Stress-Surveillance by $\gamma \delta$ T Cells. Front. Immunol. 2018, 9, 851. [CrossRef]

72. Hudspeth, K.; Silva-Santos, B.; Mavilio, D. Natural cytotoxicity receptors: Broader expression patterns and functions in innate and adaptive immune cells. Front. Immunol. 2013, 4, 69. [CrossRef] [PubMed]

73. Di Lorenzo, B.; Simões, A.E.; Caiado, F.; Tieppo, P.; Correia, D.V.; Carvalho, T.; da Silva, M.G.; Déchanet-Merville, J.; Schumacher, T.N.; Prinz, I.; et al. Broad Cytotoxic Targeting of Acute Myeloid Leukemia by Polyclonal Delta One T Cells. Cancer Immunol. Res. 2019, 7, 552-558. [CrossRef] [PubMed]

74. Witherden, D.A.; Havran, W.L. EPCR: A stress trigger for $\gamma \delta$ T cells. Nat. Immunol. 2012, 13, 812-814. [CrossRef] [PubMed]

75. Stam, A.; de Bruin, R.; Roovers, R.; van Bergen en Henegouwen, P.; Verheul, H.; de Gruijl, T.D.; van der Vliet, H. Specific tumor targeting and activation of $\mathrm{V} \gamma 9 \mathrm{~V} \delta 2 \mathrm{~T}$ cells by bi-specific nanobodies. J. Immunother. Cancer 2014, 2, 127. [CrossRef]

76. Li, Z.; Peng, H.; Xu, Q.; Ye, Z. Sensitization of human osteosarcoma cells to V $\gamma 9 \mathrm{~V} \delta 2$ T-cell-mediated cytotoxicity by zoledronate. J. Orthop. Res. 2012, 30, 824-830. [CrossRef] 
77. D'Asaro, M.; La Mendola, C.; Di Liberto, D.; Orlando, V.; Todaro, M.; Spina, M.; Guggino, G.; Meraviglia, S.; Caccamo, N.; Messina, A.; et al. V gamma 9V delta $2 \mathrm{~T}$ lymphocytes efficiently recognize and kill zoledronate-sensitized, imatinib-sensitive, and imatinib-resistant chronic myelogenous leukemia cells. J. Immunother. 2010, 184, 3260-3268.

78. Wu, D.; Wu, P.; Wu, X.; Ye, J.; Wang, Z.; Zhao, S.; Ni, C.; Hu, G.; Xu, J.; Han, Y.; et al. expanded human circulating V $\delta 1 \gamma \delta \mathrm{T}$ cells exhibit favorable therapeutic potential for colon cancer. Oncoimmunology 2015, 4, e992749. [CrossRef]

79. Halary, F.; Pitard, V.; Dlubek, D.; Krzysiek, R.; de la Salle, H.; Merville, P.; Dromer, C.; Emilie, D.; Moreau, J.-F.; Déchanet-Merville, J. Shared reactivity of V $\delta 2 \mathrm{neg} \gamma \delta \mathrm{T}$ cells against cytomegalovirus-infected cells and tumor intestinal epithelial cells. J. Exp. Med. 2005, 201, 1567-1578. [CrossRef]

80. Tokuyama, H.; Hagi, T.; Mattarollo, S.R.; Morley, J.; Wang, Q.; So, H.-F.; Fai-So, H.; Moriyasu, F.; Nieda, M.; Nicol, A.J. V gamma $9 \mathrm{~V}$ delta $2 \mathrm{~T}$ cell cytotoxicity against tumor cells is enhanced by monoclonal antibody drugs-rituximab and trastuzumab. Int. J. Cancer 2008, 122, 2526-2534. [CrossRef]

81. Gertner-Dardenne, J.; Bonnafous, C.; Bezombes, C.; Capietto, A.-H.; Scaglione, V.; Ingoure, S.; Cendron, D.; Gross, E.; Lepage, J.-F.; Quillet-Mary, A.; et al. Bromohydrin pyrophosphate enhances antibody-dependent cell-mediated cytotoxicity induced by therapeutic antibodies. Blood 2009, 113, 4875-4884. [CrossRef] [PubMed]

82. Capietto, A.-H.; Martinet, L.; Fournié, J.-J. Stimulated $\gamma \delta$ T cells increase the in vivo efficacy of trastuzumab in HER-2+ breast cancer. J. Immunother. 2011, 187, 1031-1038. [CrossRef] [PubMed]

83. Caccamo, N.; Battistini, L.; Bonneville, M.; Poccia, F.; Fournié, J.J.; Meraviglia, S.; Borsellino, G.; Kroczek, R.A.; La Mendola, C.; Scotet, E.; et al. CXCR5 identifies a subset of Vgamma9Vdelta2 T cells which secrete IL-4 and IL-10 and help B cells for antibody production. J. Immunother. 2006, 177, 5290-5295.

84. Bansal, R.R.; Mackay, C.R.; Moser, B.; Eberl, M. IL-21 enhances the potential of human $\gamma \delta$ T cells to provide B-cell help. Eur. J. Immunol. 2012, 42, 110-119. [CrossRef]

85. Crawford, G.; Hayes, M.D.; Seoane, R.C.; Ward, S.; Dalessandri, T.; Lai, C.; Healy, E.; Kipling, D.; Proby, C.; Moyes, C.; et al. Epithelial damage and tissue $\gamma \delta \mathrm{T}$ cells promote a unique tumor-protective IgE response. Nat. Immunol. 2018, 19, 859-870. [CrossRef]

86. Rezende, R.M.; Lanser, A.J.; Rubino, S.; Kuhn, C.; Skillin, N.; Moreira, T.G.; Liu, S.; Gabriely, G.; David, B.A.; Menezes, G.B.; et al. $\gamma \delta \mathrm{T}$ cells control humoral immune response by inducing $\mathrm{T}$ follicular helper cell differentiation. Nat. Commun. 2018, 9, 3151. [CrossRef]

87. Brandes, M.; Willimann, K.; Moser, B. Professional antigen-presentation function by human gammadelta T Cells. Science 2005, 309, 264-268. [CrossRef]

88. Mao, C.; Mou, X.; Zhou, Y.; Yuan, G.; Xu, C.; Liu, H.; Zheng, T.; Tong, J.; Wang, S.; Chen, D. Tumor-activated $\mathrm{TCR} \gamma \delta^{+} \mathrm{T}$ cells from gastric cancer patients induce the antitumor immune response of TCR $\alpha \beta^{+} \mathrm{T}$ cells via their antigen-presenting cell-like effects. J. Immunol. Res. 2014, 2014, 593562. [CrossRef]

89. Muto, M.; Baghdadi, M.; Maekawa, R.; Wada, H.; Seino, K.-I. Myeloid molecular characteristics of human $\gamma \delta$ $\mathrm{T}$ cells support their acquisition of tumor antigen-presenting capacity. Cancer Immunol. Immunother. 2015, 64, 941-949. [CrossRef]

90. Maniar, A.; Zhang, X.; Lin, W.; Gastman, B.R.; Pauza, C.D.; Strome, S.E.; Chapoval, A.I. Human gammadelta T lymphocytes induce robust NK cell-mediated antitumor cytotoxicity through CD137 engagement. Blood 2010, 116, 1726-1733. [CrossRef]

91. Van Acker, H.H.; Anguille, S.; Van Tendeloo, V.F.; Lion, E. Empowering gamma delta T cells with antitumor immunity by dendritic cell-based immunotherapy. Oncoimmunology 2015, 4, e1021538. [CrossRef] [PubMed]

92. Conti, L.; Casetti, R.; Cardone, M.; Varano, B.; Martino, A.; Belardelli, F.; Poccia, F.; Gessani, S. Reciprocal activating interaction between dendritic cells and pamidronate-stimulated gammadelta T cells: Role of CD86 and inflammatory cytokines. J. Immunother. 2005, 174, 252-260.

93. Zou, W. Mechanistic insights into cancer immunity and immunotherapy. Cell. Mol. Immunol. 2018, 15, 419-420. [CrossRef] [PubMed]

94. Huang, L.; Xu, H.; Peng, G. TLR-mediated metabolic reprogramming in the tumor microenvironment: Potential novel strategies for cancer immunotherapy. Cell. Mol. Immunol. 2018, 15, 428-437. [CrossRef] [PubMed]

95. Wu, Y.-L.; Ding, Y.-P.; Tanaka, Y.; Shen, L.-W.; Wei, C.-H.; Minato, N.; Zhang, W. $\gamma \delta$ T cells and their potential for immunotherapy. Int. J. Biol. Sci. 2014, 10, 119-135. [CrossRef] 
96. Lo Presti, E.; Pizzolato, G.; Gulotta, E.; Cocorullo, G.; Gulotta, G.; Dieli, F.; Meraviglia, S. Current Advances in gammadelta T Cell-Based Tumor Immunotherapy. Front. Immunol. 2017, 8, 1401. [CrossRef]

97. Zysk, A.; DeNichilo, M.O.; Panagopoulos, V.; Zinonos, I.; Liapis, V.; Hay, S.; Ingman, W.; Ponomarev, V.; Atkins, G.; Findlay, D.; et al. Adoptive transfer of ex vivo expanded V $\gamma 9 \mathrm{~V} \delta 2 \mathrm{~T}$ cells in combination with zoledronic acid inhibits cancer growth and limits osteolysis in a murine model of osteolytic breast cancer. Cancer Lett. 2017, 386, 141-150. [CrossRef]

98. Wada, I.; Matsushita, H.; Noji, S.; Mori, K.; Yamashita, H.; Nomura, S.; Shimizu, N.; Seto, Y.; Kakimi, K. Intraperitoneal injection of in vitro expanded $\mathrm{V} \gamma 9 \mathrm{~V} \delta 2 \mathrm{~T}$ cells together with zoledronate for the treatment of malignant ascites due to gastric cancer. Cancer Med. 2014, 3, 362-375. [CrossRef]

99. Bennouna, J.; Levy, V.; Sicard, H.; Senellart, H.; Audrain, M.; Hiret, S.; Rolland, F.; Bruzzoni-Giovanelli, H.; Rimbert, M.; Galéa, C.; et al. Phase I study of bromohydrin pyrophosphate (BrHPP, IPH 1101), a Vgamma9Vdelta2 T lymphocyte agonist in patients with solid tumors. Cancer Immunol. Immunother. 2010, 59, 1521-1530. [CrossRef]

100. Bennouna, J.; Bompas, E.; Neidhardt, E.M.; Rolland, F.; Philip, I.; Galéa, C.; Salot, S.; Saiagh, S.; Audrain, M.; Rimbert, M.; et al. Phase-I study of Innacell gammadelta, an autologous cell-therapy product highly enriched in gamma9delta2 $\mathrm{T}$ lymphocytes, in combination with IL-2, in patients with metastatic renal cell carcinoma. Cancer Immunol. Immunother. 2008, 57, 1599-1609. [CrossRef]

101. Nakajima, J.; Murakawa, T.; Fukami, T.; Goto, S.; Kaneko, T.; Yoshida, Y.; Takamoto, S.; Kakimi, K. A phase I study of adoptive immunotherapy for recurrent non-small-cell lung cancer patients with autologous gammadelta T cells. Eur. J. Cardio-Thorac. Surg. 2010, 37, 1191-1197. [CrossRef] [PubMed]

102. Sakamoto, M.; Nakajima, J.; Murakawa, T.; Fukami, T.; Yoshida, Y.; Murayama, T.; Takamoto, S.; Matsushita, H.; Kakimi, K. Adoptive immunotherapy for advanced non-small cell lung cancer using zoledronate-expanded $\gamma \delta$ Tcells: A phase I clinical study. J. Immunother. 2011, 34, 202-211. [CrossRef] [PubMed]

103. Nicol, A.J.; Tokuyama, H.; Mattarollo, S.R.; Hagi, T.; Suzuki, K.; Yokokawa, K.; Nieda, M. Clinical evaluation of autologous gamma delta T cell-based immunotherapy for metastatic solid tumours. Br. J. Cancer 2011, 105, 778-786. [CrossRef] [PubMed]

104. Kobayashi, H.; Tanaka, Y.; Yagi, J.; Minato, N.; Tanabe, K. Phase I/II study of adoptive transfer of $\gamma \delta$ $\mathrm{T}$ cells in combination with zoledronic acid and IL-2 to patients with advanced renal cell carcinoma. Cancer Immunol. Immunother. 2011, 60, 1075-1084. [CrossRef]

105. Abe, Y.; Muto, M.; Nieda, M.; Nakagawa, Y.; Nicol, A.; Kaneko, T.; Goto, S.; Yokokawa, K.; Suzuki, K. Clinical and immunological evaluation of zoledronate-activated Vgamma9gammadelta T-cell-based immunotherapy for patients with multiple myeloma. Exp. Hematol. 2009, 37, 956-968. [CrossRef]

106. Kobayashi, H.; Tanaka, Y.; Yagi, J.; Osaka, Y.; Nakazawa, H.; Uchiyama, T.; Minato, N.; Toma, H. Safety profile and anti-tumor effects of adoptive immunotherapy using gamma-delta $\mathrm{T}$ cells against advanced renal cell carcinoma: A pilot study. Cancer Immunol. Immunother. 2007, 56, 469-476. [CrossRef]

107. Wilhelm, M.; Kunzmann, V.; Eckstein, S.; Reimer, P.; Weissinger, F.; Ruediger, T.; Tony, H.-P. Gammadelta T cells for immune therapy of patients with lymphoid malignancies. Blood 2003, 102, 200-206. [CrossRef]

108. Kunzmann, V.; Smetak, M.; Kimmel, B.; Weigang-Koehler, K.; Goebeler, M.; Birkmann, J.; Becker, J.; Schmidt-Wolf, I.G.H.; Einsele, H.; Wilhelm, M. Tumor-promoting versus tumor-antagonizing roles of $\gamma \delta$ T cells in cancer immunotherapy: Results from a prospective phase I/II trial. J. Immunother. 2012, 35, $205-213$. [CrossRef]

109. Lang, J.M.; Kaikobad, M.R.; Wallace, M.; Staab, M.J.; Horvath, D.L.; Wilding, G.; Liu, G.; Eickhoff, J.C.; McNeel, D.G.; Malkovsky, M. Pilot trial of interleukin-2 and zoledronic acid to augment $\gamma \delta \mathrm{T}$ cells as treatment for patients with refractory renal cell carcinoma. Cancer Immunol. Immunother. 2011, 60, 1447-1460. [CrossRef]

110. Pressey, J.G.; Adams, J.; Harkins, L.; Kelly, D.; You, Z.; Lamb, L.S. In vivo expansion and activation of $\gamma \delta$ T cells as immunotherapy for refractory neuroblastoma: A phase 1 study. Medicine 2016, 95, e4909. [CrossRef]

111. Kouakanou, L.; Xu, Y.; Peters, C.; He, J.; Wu, Y.; Yin, Z.; Kabelitz, D. Vitamin C promotes the proliferation and effector functions of human $\gamma \delta$ T cells. Cell. Mol. Immunol. 2019. [CrossRef] [PubMed]

112. Siegers, G.M.; Lamb, L.S. Cytotoxic and regulatory properties of circulating V $\delta 1+\gamma \delta$ T cells: A new player on the cell therapy field? Mol. Ther. 2014, 22, 1416-1422. [CrossRef] [PubMed]

113. Meraviglia, S.; Dieli, F. Clonal expansion shapes the human V81T cell receptor repertoire. Cell. Mol. Immunol. 2018, 15, 96-98. [CrossRef] [PubMed] 
114. Oberg, H.-H.; Peipp, M.; Kellner, C.; Sebens, S.; Krause, S.; Petrick, D.; Adam-Klages, S.; Röcken, C.; Becker, T.; Vogel, I.; et al. Novel bispecific antibodies increase $\gamma \delta$ T-cell cytotoxicity against pancreatic cancer cells. Cancer Res. 2014, 74, 1349-1360. [CrossRef] [PubMed]

115. Oberg, H.-H.; Kellner, C.; Gonnermann, D.; Peipp, M.; Peters, C.; Sebens, S.; Kabelitz, D.; Wesch, D. $\gamma \delta$ T cell activation by bispecific antibodies. Cell. Immunol. 2015, 296, 41-49. [CrossRef]

116. de Bruin, R.C.G.; Veluchamy, J.P.; Lougheed, S.M.; Schneiders, F.L.; Lopez-Lastra, S.; Lameris, R.; Stam, A.G.; Sebestyen, Z.; Kuball, J.; Molthoff, C.F.M.; et al. A bispecific nanobody approach to leverage the potent and widely applicable tumor cytolytic capacity of V $\gamma 9 \mathrm{~V} \delta 2-\mathrm{T}$ cells. Oncoimmunology 2017, 7, e1375641. [CrossRef]

117. Oberg, H.H.; Kellner, C.; Gonnermann, D.; Sebens, S.; Bauerschlag, D.; Gramatzki, M.; Kabelitz, D.; Peipp, M.; Wesch, D. Tribody [(HER2)xCD16] Is More Effective Than Trastuzumab in Enhancing $\gamma \delta$ T Cell and Natural Killer Cell Cytotoxicity Against HER2-Expressing Cancer Cells. Front. Immunol. 2018, 9, 814. [CrossRef]

118. Johnson, L.A.; June, C.H. Driving gene-engineered T cell immunotherapy of cancer. Cell Res. 2017, $27,38-58$. [CrossRef]

119. Shah, N.N.; Fry, T.J. Mechanisms of resistance to CAR T cell therapy. Nat. Rev. Clin. Oncol. 2019, 16, 372-385. [CrossRef]

120. Deniger, D.C.; Moyes, J.S.; Cooper, L.J.N. Clinical applications of gamma delta T cells with multivalent immunity. Front. Immunol. 2014, 5, 636. [CrossRef]

121. Deniger, D.C.; Switzer, K.; Mi, T.; Maiti, S.; Hurton, L.; Singh, H.; Huls, H.; Olivares, S.; Lee, D.A.; Champlin, R.E.; et al. Bispecific T-cells expressing polyclonal repertoire of endogenous $\gamma \delta$ T-cell receptors and introduced CD19-specific chimeric antigen receptor. Mol. Ther. 2013, 21, 638-647. [CrossRef] [PubMed]

122. Fisher, J.; Abramowski, P.; Wisidagamage Don, N.D.; Flutter, B.; Capsomidis, A.; Cheung, G.W.-K.; Gustafsson, K.; Anderson, J. Avoidance of On-Target Off-Tumor Activation Using a Co-stimulation-Only Chimeric Antigen Receptor. Mol. Ther. 2017, 25, 1234-1247. [CrossRef] [PubMed]

123. Capsomidis, A.; Benthall, G.; Van Acker, H.H.; Fisher, J.; Kramer, A.M.; Abeln, Z.; Majani, Y.; Gileadi, T.; Wallace, R.; Gustafsson, K.; et al. Chimeric Antigen Receptor-Engineered Human Gamma Delta T Cells: Enhanced Cytotoxicity with Retention of Cross Presentation. Mol. Ther. 2018, 26, 354-365. [CrossRef]

124. Gründer, C.; van Dorp, S.; Hol, S.; Drent, E.; Straetemans, T.; Heijhuurs, S.; Scholten, K.; Scheper, W.; Sebestyen, Z.; Martens, A.; et al. $\gamma 9$ and $\delta 2 \mathrm{CDR} 3$ domains regulate functional avidity of $\mathrm{T}$ cells harboring $\gamma 9 \delta 2$ TCRs. Blood 2012, 120, 5153-5162. [CrossRef] [PubMed]

125. Marcu-Malina, V.; Heijhuurs, S.; van Buuren, M.; Hartkamp, L.; Strand, S.; Sebestyen, Z.; Scholten, K.; Martens, A.; Kuball, J. Redirecting $\alpha \beta$ T cells against cancer cells by transfer of a broadly tumor-reactive $\gamma \delta$ T-cell receptor. Blood 2011, 118, 50-59. [CrossRef] [PubMed]

126. Braham, M.V.J.; Minnema, M.C.; Aarts, T.; Sebestyen, Z.; Straetemans, T.; Vyborova, A.; Kuball, J.; Öner, F.C.; Robin, C.; Alblas, J. Cellular immunotherapy on primary multiple myeloma expanded in a 3D bone marrow niche model. Oncoimmunology 2018, 7, e1434465. [CrossRef] [PubMed]

127. Straetemans, T.; Kierkels, G.J.J.; Doorn, R.; Jansen, K.; Heijhuurs, S.; Dos Santos, J.M.; van Muyden, A.D.D.; Vie, H.; Clemenceau, B.; Raymakers, R.; et al. GMP-Grade Manufacturing of T Cells Engineered to Express a Defined $\gamma \delta$ TCR. Front. Immunol. 2018, 9, 1062. [CrossRef]

128. Ribas, A.; Wolchok, J.D. Cancer immunotherapy using checkpoint blockade. Science 2018, 359, $1350-1355$. [CrossRef]

129. Zhang, X.; Cheng, C.; Hou, J.; Qi, X.; Wang, X.; Han, P.; Yang, X. Distinct contribution of PD-L1 suppression by spatial expression of PD-L1 on tumor and non-tumor cells. Cell. Mol. Immunol. 2019, 16, 392-400. [CrossRef]

130. Yu, G.; Wu, Y.; Wang, W.; Xu, J.; Lv, X.; Cao, X.; Wan, T. Low-dose decitabine enhances the effect of PD-1 blockade in colorectal cancer with microsatellite stability by re-modulating the tumor microenvironment. Cell. Mol. Immunol. 2019, 16, 401-409. [CrossRef]

131. Li, X.; Song, W.; Shao, C.; Shi, Y.; Han, W. Emerging predictors of the response to the blockade of immune checkpoints in cancer therapy. Cell. Mol. Immunol. 2019, 16, 28-39. [CrossRef] [PubMed]

132. Li, X.; Lu, H.; Gu, Y.; Zhang, X.; Zhang, G.; Shi, T.; Chen, W. Tim-3 suppresses the killing effect of V $\gamma 9 \mathrm{~V} \delta 2 \mathrm{~T}$ cells on colon cancer cells by reducing perforin and granzyme B expression. Exp. Cell Res. 2020, 386, 111719. [CrossRef]

133. Rossi, C.; Gravelle, P.; Decaup, E.; Bordenave, J.; Poupot, M.; Tosolini, M.; Franchini, D.-M.; Laurent, C.; Morin, R.; Lagarde, J.-M.; et al. Boosting $\gamma \delta$ T cell-mediated antibody-dependent cellular cytotoxicity by PD-1 blockade in follicular lymphoma. Oncoimmunology 2019, 8, 1554175. [CrossRef] [PubMed] 
134. Mittal, D.; Gubin, M.M.; Schreiber, R.D.; Smyth, M.J. New insights into cancer immunoediting and its three component phases-elimination, equilibrium and escape. Curr. Opin. Immunol. 2014, 27, 16-25. [CrossRef] [PubMed]

135. Van Acker, H.H.; Anguille, S.; Willemen, Y.; Van den Bergh, J.M.; Berneman, Z.N.; Lion, E.; Smits, E.L.; Van Tendeloo, V.F. Interleukin-15 enhances the proliferation, stimulatory phenotype, and antitumor effector functions of human gamma delta T cells. J. Hematol. Oncol. 2016, 9, 101. [CrossRef] [PubMed]

136. Cairo, C.; Sagnia, B.; Cappelli, G.; Colizzi, V.; Leke, R.G.F.; Leke, R.J.; Pauza, C.D. Human cord blood $\gamma \delta ~ T$ cells expressing public $\mathrm{V} \gamma 2$ chains dominate the response to bisphosphonate plus interleukin-15. Immunology 2013, 138, 346-360. [CrossRef]

(C) 2020 by the authors. Licensee MDPI, Basel, Switzerland. This article is an open access article distributed under the terms and conditions of the Creative Commons Attribution (CC BY) license (http://creativecommons.org/licenses/by/4.0/). 